\title{
Bioinspired Fabrication of DNA-Inorganic Hybrid Composites Using Synthetic DNA
}

Eunjung Kim, ${ }^{\dagger}$ Shweta Agarwal, ${ }^{\dagger}$ Nayoung Kim, ${ }^{\dagger}$ Fredrik Sydow Hage, ${ }^{\dagger}$ Vincent Leonardo, ${ }^{\dagger}$ Amy Gelmi, ${ }^{\dagger}$ and Molly M. Stevens* ${ }^{*}+$ (1)

${ }^{\dagger}$ Department of Materials, Department of Bioengineering and Institute for Biomedical Engineering, Imperial College London, London SW7 2AZ, United Kingdom

${ }^{\ddagger}$ SuperSTEM Laboratory, SciTech Daresbury Campus, Daresbury WA4 4AD, United Kingdom

\section{Supporting Information}

ABSTRACT: Nucleic acid nanostructures have attracted significant interest as potential therapeutic and diagnostic platforms due to their intrinsic biocompatibility and biodegradability, structural and functional diversity, and compatibility with various chemistries for modification and stabilization. Among the fabrication approaches for such structures, the rolling circle techniques have emerged as particularly promising, producing morphologically round, flower-shaped nucleic acid particles: typically hybrid composites of long nucleic acid strands and inorganic magnesium pyrophosphate $\left(\mathrm{Mg}_{2} \mathrm{PPi}\right)$. These constructs are known to form via anisotropic nucleic acid-driven crystallization in a sequence-independent manner, rendering monodisperse and densely packed RNA or DNA-inorganic composites. However, it still remains to fully explore how flexible polymer-like RNA or DNA strands (acting as biomolecular additives) mediate the crystallization process of $\mathrm{Mg}_{2} \mathrm{PPi}$ and affect the structure and properties of the product crystals. To address this, we closely examined nanoscale details to mesoscopic features of $\mathrm{Mg}_{2} \mathrm{PPi} / \mathrm{DNA}$ hybrid composites fabricated by two approaches, namely rolling circle amplification (RCA)-based in situ synthesis and long synthetic DNA-mediated crystallization. Similar to the DNA constructs fabricated by RCA, the rapid crystallization of $\mathrm{Mg}_{2} \mathrm{PPi}$ was retarded on a short-range order when we precipitated the crystals in the presence of presynthesized long DNA, which resulted in effective incorporation of biomolecular additives such as DNA and enzymes. These findings further provide a more feasible way to encapsulate bioactive enzymes within DNA constructs compared to in situ RCA-mediated synthesis, i.e., by not only protecting them from possible denaturation under the reaction conditions but also preventing nonselective association of proteins arising from the RCA reaction mixtures.

KEYWORDS: DNA-inorganic hybrid composites, rolling circle techniques, crystallization, coprecipitation, DNA inclusion
$\mathrm{B}$ iomimetic crystallization methods have been exploited to build functional materials with a variety of specialized and complex properties similar to naturally occurring biominerals. ${ }^{1,2}$ Such methods involve homogeneous or heterogeneous nucleation and growth of organic and inorganic phases in materials, inducing highly ordered, hierarchical structures with well-defined morphologies, sizes, and polymorphs. ${ }^{2,3}$ In such a way, one can generate DNAinorganic hybrid composites mainly composed of DNA and magnesium pyrophosphate $\left(\mathrm{Mg}_{2} \mathrm{PPi}\right)$, generated by rolling circle techniques such as rolling circle amplification (RCA) or transcription (RCT) based on isothermal enzymatic polymerization. ${ }^{4,5}$ In contrast to DNA nanostructures assembled by Watson-Crick base pairing, they form morphologically spherical, flower-like nucleic acid particles through in situ nucleic acid-driven crystallization of metal salts (here $\mathrm{Mg}_{2} \mathrm{PPi}$ ) generated during the reaction. ${ }^{5-8}$ Due to their large surface areas and highly porous structures, coupled with intrinsic DNA and RNA properties and functionalities, these RCA- or RCTbased nano-/microparticles are of utility for biomedical applications. $^{4-6,8-15}$ However, further study is needed on how the presence of long DNA or RNA as organic additives and structure-directing agents-whether they are in situ synthesized or presynthesized-can modulate the $\mathrm{Mg}_{2} \mathrm{PPi}$ crystal growth and direct the outcome structures of particles during the RCA or RCT process.

Received: August 25, 2018

Accepted: February 6, 2019

Published: February 11, 2019 
Scheme 1. Overview of the Fabrication of DNA-Inorganic Hybrid Composites ${ }^{a}$

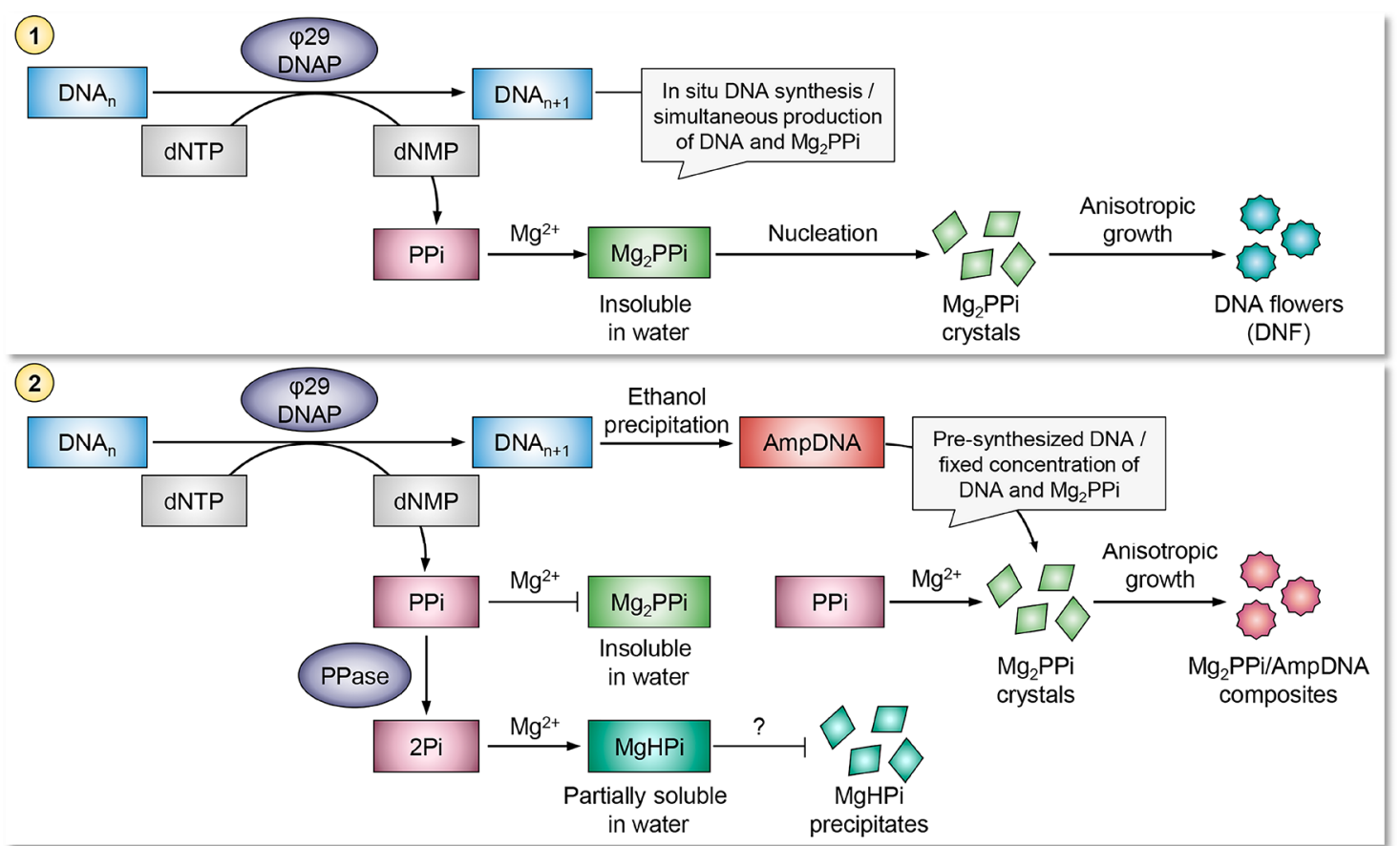

${ }^{a}$ Key: (1) DNA flowers (DNF) constructed by a one-pot enzymatic process using rolling circle amplification (RCA) and (2) $\mathrm{Mg}_{2} \mathrm{PPi} / \mathrm{AmpDNA}$ composites formed by synthetic DNA-driven crystallization, in which abundant Mg and PPi ions precipitated in the presence of amplified DNA (AmpDNA). The AmpDNA was obtained from the RCA reaction with the addition of pyrophosphatase (PPase) and subsequent ethanol precipitation. Deoxynucleoside triphosphate (dNTP), deoxynucleoside monophosphate (dNMP), phi29 DNA polymerase ( $\varphi 29$ DNAP), pyrophosphate $\left(\mathrm{PPi}, \mathrm{P}_{2} \mathrm{O}_{7}\right)$, phosphate $(\mathrm{Pi})$, magnesium pyrophosphate $\left(\mathrm{Mg}_{2} \mathrm{PPi}\right)$, and magnesium hydrogen phosphate $(\mathrm{MgHPi})$.

Indeed, there is a lack of reports showing how the $\mathrm{Mg}_{2} \mathrm{PPi}$ crystals evolve chemically and morphologically by the introduction of DNA or RNA molecules during the reaction. While Shopsowitz et al. demonstrated that addition of RNA into a certain concentration of $\mathrm{Mg}_{2} \mathrm{PPi}$ dramatically changed the particle morphology compared to that without RNA, ${ }^{7}$ more substantial evidence is required to fully understand the role of the produced RNA molecules during the RCT process. Apart from the typical RCA-based fabrication of DNA particles, various RCA-inspired approaches have been recently proposed by focusing more on the critical role of divalent cations in controlling size, morphology, and functionality of the resulting DNA particles. ${ }^{16-18}$ These approaches present an effective route for preparation of functional DNA-inorganic hybrid particles. However, studying how the inclusion of long DNA serving as organic additives in $\mathrm{Mg}_{2} \mathrm{PPi}$ crystal growth affects the molecular interaction between DNA and inorganic crystals still remains unexplored. These organic macromolecules appear to be intimately associated with the $\mathrm{Mg}_{2} \mathrm{PPi}$ phase through mainly electrostatic interaction in common with RCA-driven in situ formation of DNA particles, where multiple interactions occur between growing DNA and $\mathrm{Mg}_{2} \mathrm{PPi}$ over time.

Moreover, the majority of characterizations of RCA- or RCT-based particles have so far focused on their surface morphology, composition, and size using scanning and transmission electron microscopy (SEM and TEM). In terms of nanostructural investigation, multimodal coherent X-ray diffraction analysis of RCT-mediated RNA microparticles (termed RNAi microsponges) recently revealed the existence of a dense internal core region within the particles. ${ }^{19}$ This technique allows for two- and three-dimensional electron density imaging of such biological materials at the nanoscale. However, this method does not provide detailed chemical and atomic information that would demonstrate molecular relationships between organic and inorganic matter within the RNAi microsponges.

Here, we studied and identified the differences in the nanostructural morphology, chemical composition, atomic bonding configuration, and crystallinity of various $\mathrm{Mg}_{2} \mathrm{PPi} /$ DNA composites prepared by two RCA-inspired approaches. We used various advanced characterization methods, including high-resolution scanning transmission electron microscopy (STEM) imaging in combination with energy dispersive X-ray spectroscopy (EDS) and electron energy loss spectroscopy (EELS), X-ray diffraction (XRD), and Raman spectroscopy.

\section{RESULTS AND DISCUSSION}

Motivated by our previous study, ${ }^{8}$ we further question how presynthesized long DNA (specifically isolated from the RCA) can affect the structure and chemical pathways controlling the organization process of $\mathrm{Mg}_{2} \mathrm{PPi}$ crystals in comparison to in situ synthesized DNA-driven $\mathrm{Mg}_{2} \mathrm{PPi}$ growth. To address this, we designed two strategies for fabrication of $\mathrm{Mg}_{2} \mathrm{PPi} / \mathrm{DNA}$ hybrid composites based on (1) in situ RCA-driven synthesis and (2) a synthetic DNA-directed crystallization method (Scheme 1). During the in situ synthesis, continuously growing DNA strands and $\mathrm{Mg}_{2} \mathrm{PPi}$ crystals formed hierarchical, flowershaped DNA structures (termed DNF hereafter) for the desired reaction time ( $20 \mathrm{~h}$ in this study). On the other hand, in the synthetic DNA-driven crystallization method, we first solely isolated the amplified DNA (AmpDNA) from the products after $20 \mathrm{~h} \mathrm{RCA}$ in the presence of inorganic pyrophosphatase (PPase) through subsequent purification by 

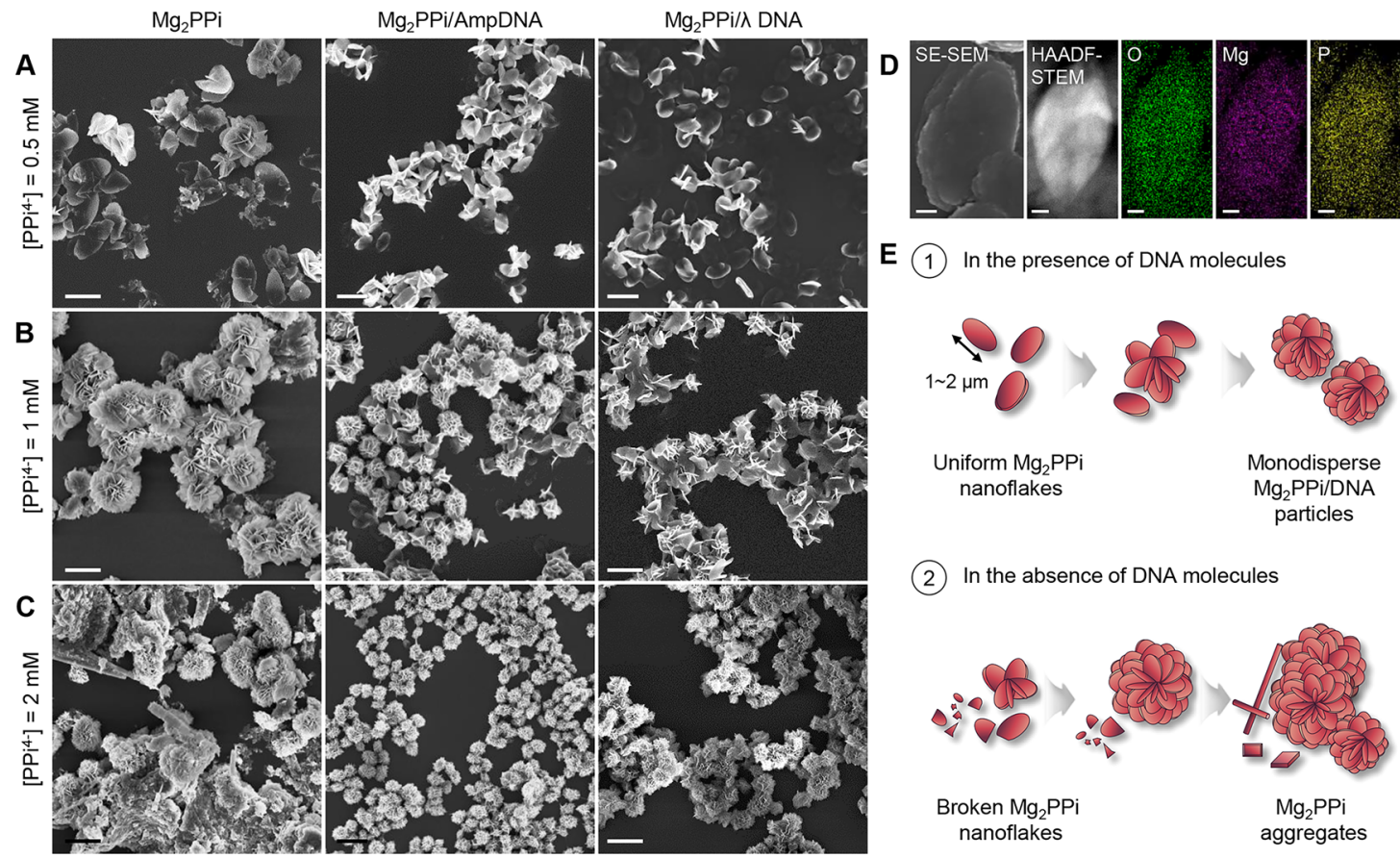

E (1) In the presence of DNA molecules

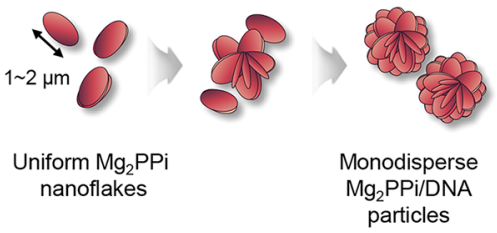

(2) In the absence of DNA molecules

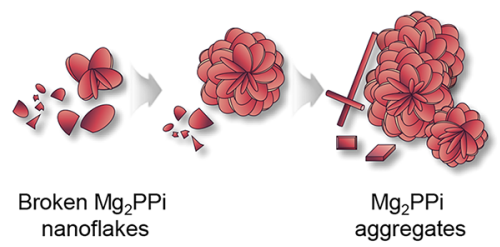

Figure 1. Inclusion of DNA as an organic additive in the formation of $\mathrm{Mg}_{2} \mathrm{PPi}$ crystals. Representative SE-SEM images of the grown $\mathrm{Mg}_{2} \mathrm{PPi}$ crystals after $20 \mathrm{~h}$ crystallization in the absence (left) and presence of AmpDNA (middle) and $\lambda$ DNA (right) at a fixed concentration of DNA $\left(26.7 \mu \mathrm{g} \mathrm{mL}^{-1}\right)$ and PPi ion concentrations of (A) 0.5 , (B) 1 , and (C) $2 \mathrm{mM}$, where morphological changes are observed with increasing PPi ion concentrations. Scale bar, $2 \mu \mathrm{m}$. (D) SE-SEM and HAADF-STEM images of a nanoflake with ellipsoidal shape observed in the presence of $0.5 \mathrm{mM}$ of $\mathrm{Mg}_{2} \mathrm{PPi}$. The EDS elemental maps confirmed the presence of oxygen $(\mathrm{O})$, magnesium $(\mathrm{Mg})$, and phosphorus (P) in the nanoflake. Scale bar, $200 \mathrm{~nm}$. (E) Schematic illustration of the proposed role of DNA molecules in the regulation of the anisotropic growth of the $\mathrm{Mg}_{2} \mathrm{PPi}$ nanoflakes.

ethanol precipitation. After removal of salts and proteins, the resulting AmpDNA was then precipitated out in a neutral buffer containing concentrated $\mathrm{Mg}$ and PPi ions (for $20 \mathrm{~h}$ ) in order to produce another class of DNA-inorganic hybrid composites (termed $\mathrm{Mg}_{2} \mathrm{PPi} / \mathrm{AmpDNA}$ hereafter).

In the RCA reaction, the phi29 DNA polymerase ( $\varphi 29$ DNAP) simultaneously produces DNA strands and pyrophosphate $\left(\mathrm{PPi}^{4-}\right)$ ions in a time-dependent manner. ${ }^{8}$ The released anionic PPi ions tend to form insoluble $\mathrm{Mg}_{2} \mathrm{PPi}$ precipitates with cationic magnesium $\left(\mathrm{Mg}^{2+}\right)$ ions supplied from the reaction buffer when they reach a sufficient concentration. On the other hand, the addition of PPase to the RCA reaction mixtures converts $\mathrm{PPi}$ to phosphate $(\mathrm{Pi})$ ions and inhibits the formation of $\mathrm{Mg}_{2} \mathrm{PPi}$ precipitates. As a result, long DNA strands are produced rather than DNA particles. The released $\mathrm{Pi}$ ions may also be involved in the formation of magnesium hydrogen phosphate $(\mathrm{MgHPi})$ complexes, which are partially soluble in aqueous solution. In addition to $\mathrm{MgHPi}$, several ionic species and complexes, including free $\mathrm{Mg}$ ions, $\mathrm{PPi}$ ions, $\mathrm{MgPPi}$ ions, $\mathrm{MgHPPi}$ ions, $\mathrm{Mg}_{2} \mathrm{PPi}$, etc., may be present in the initial RCA reaction mixture or be produced as the reaction proceeds. ${ }^{20}$ However, it is important to note that when we added PPase we did not observe any precipitates or particles remaining after the RCA reaction and several washing steps, possibly due to the low amount of those complexes present in reaction solution being below the solubility limit (data not shown).

We first prepared AmpDNA by performing RCA with the addition of PPase and purification, as described above (see detailed experimental procedures in the Materials and Methods). In a typical nucleic acid amplification process using a DNA polymerase, the precipitation of $\mathrm{Mg}_{2} \mathrm{PPi}$ gives rise to inhibition of DNA synthesis by causing a gradual decrease in free $\mathrm{Mg}$ ions required for DNAP activity in the reaction solution over time. ${ }^{21,22}$ Therefore, when PPase was added to the RCA reaction mixtures, the production of DNA slightly increased due to the reduced amount of PPi as compared to the RCA products without PPase (Figure S1). We then examined the structural nature of AmpDNA by UVvis absorption and circular dichroism (CD) spectroscopy. For comparison, we used phage lambda DNA ( $\lambda$ DNA), which is about $48.5 \mathrm{~kb}$ in length. The AmpDNA showed a single characteristic band at $260 \mathrm{~nm}$ in a UV-vis spectrum, a negative peak at $245 \mathrm{~nm}$, and a positive peak at $280 \mathrm{~nm}$ in a CD spectrum, which are consistent with spectra of doublestranded $\lambda$ DNA (Figure S2a,b). Both DNA solutions have absorbance ratios of ca. 1.87 and ca. 1.85 at $260 \mathrm{~nm} / 280 \mathrm{~nm}$, suggesting that they are of suitable purity for the next fabrication step. In the agarose gel electrophoresis analysis, the AmpDNA appeared as a high-molecular-weight band ( $>35$ $\mathrm{kb})$, indicating that the RCA products were successfully synthesized. To gain more insight into the structure, we visualized both DNAs prepared on mica by atomic force microscopy (AFM) imaging in tapping mode (Figure $S 2 c, d$ ). The AmpDNA showed high-order complex, supercoiled, and elongated DNA strands with an average height of $0.47 \pm 0.03$ $\mathrm{nm}$. While the AmpDNA showed double-stranded DNA (dsDNA)-like features from the CD spectrum and AFM imaging similar to $\lambda \mathrm{DNA}$, it is well accepted that the RCA process robustly produces very long and concatemeric singlestranded DNA (ssDNA) products, in which the amplified DNA is continuously displaced from the cyclic template DNA by a $\varphi 29$ DNAP. These RCA products have been extensively exploited as functional ssDNA units capable of binding to 

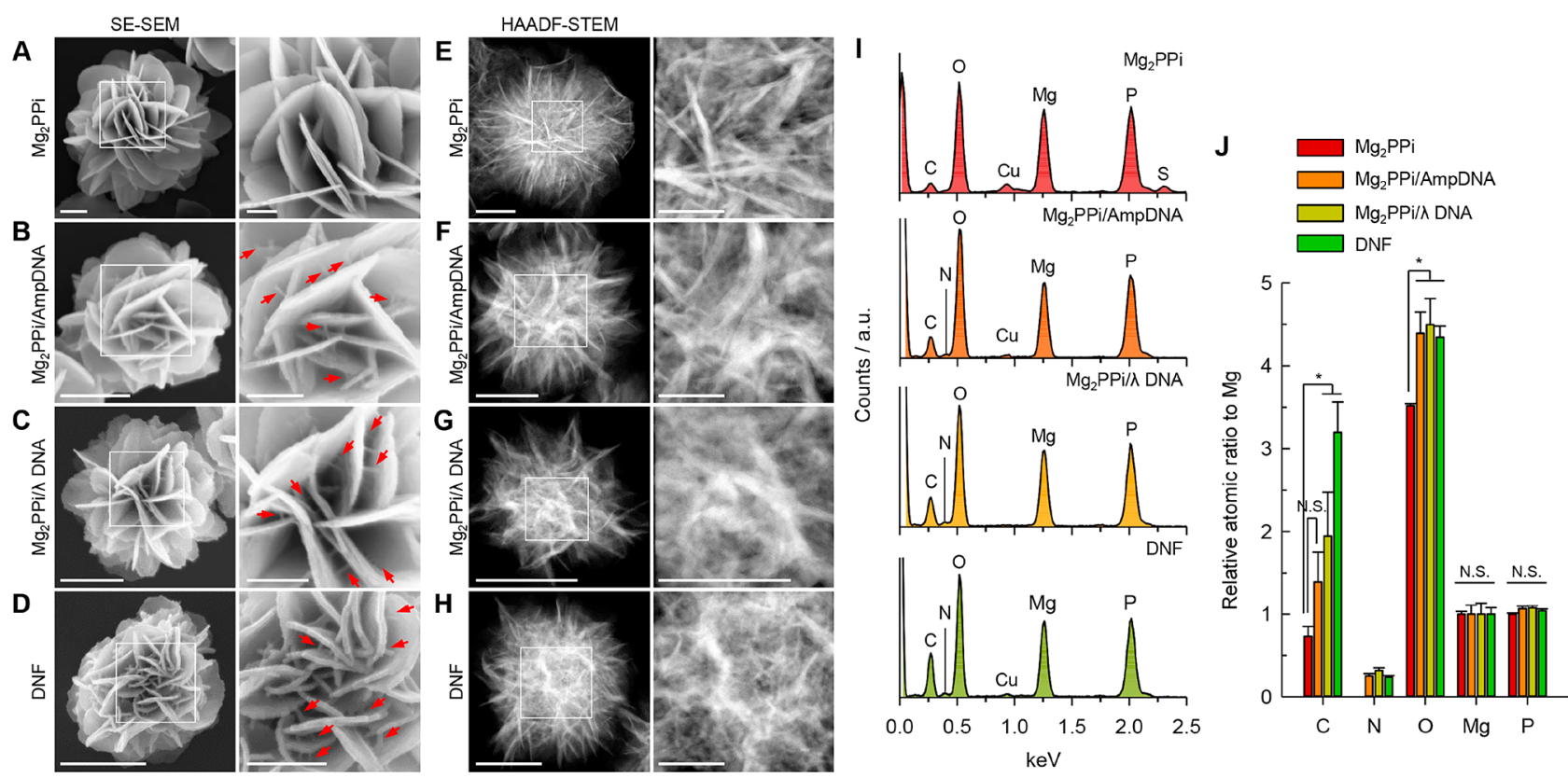

Figure 2. Structure and elemental composition of DNA-included $\mathrm{Mg}_{2} \mathrm{PPi}$ composites. (A-D) Representative SE-SEM images of the Mg $\mathrm{PPi}_{2}$ crystals precipitated in (A) the absence and presence of (B) $26.7 \mu \mathrm{g} \mathrm{mL}^{-1}$ AmpDNA or (C) $26.7 \mu \mathrm{g} \mathrm{mL}^{-1} \lambda$ DNA with $2 \mathrm{mM} \mathrm{Mg} 2 \mathrm{PPi}$. (D) In comparison, DNF was synthesized through one-step RCA reaction. High-magnification images show the presence of thin lines connecting the nanoflakes (indicated by red arrows) for $\mathrm{Mg}_{2} \mathrm{PPi} / \mathrm{DNA}$ and $\mathrm{DNF}$, in contrast to the smooth nanoflake surfaces of $\mathrm{Mg}_{2} \mathrm{PPi}$. Scale bars, 500 $\mathrm{nm}(\mathrm{A}-\mathrm{D}$, left) and $200 \mathrm{~nm}$ (A-D, right). (E-H) Representative HAADF-STEM images of each composite. The particle regions from which the higher magnification images (right) originated are indicated by boxes on the lower magnification HAADF-STEM images (left). Scale bars, $500 \mathrm{~nm}(\mathrm{E}-\mathrm{H}$, left $)$ and $200 \mathrm{~nm}(\mathrm{E}-\mathrm{H}$, right). (I) EDS spectra recorded from entire individual particles. (J) Relative atomic ratios of each element, $\mathrm{C}, \mathrm{N}, \mathrm{O}, \mathrm{Mg}$, and $\mathrm{P}$ to $\mathrm{Mg}$ for each particle type. Data represent mean \pm standard deviation (s.d.) of the EDS measurements determined over five particles. N.S. (not significant, $p>0.05$ ) and $* p<0.001$ based on one-way ANOVA and Tukey test's multiple comparison.

single-stranded oligonucleotides or forming secondary structures such as DNA aptamers, DNAzymes, and G-quadruplexes. $^{23}$ To study the nature of AmpDNA as RCA products, we performed thorough analysis of AmpDNA with several exoand endonucleases and SYBR dyes specific for ssDNA and/or dsDNA cleavage and staining (see more details of experimental procedures and analysis in the Supporting Information, Figure S3 and Table S2). We believe that the prepared AmpDNA as single-stranded RCA products represent a mix of ssDNA and dsDNA but most likely form a large amount of dsDNA-like conformations as a result of random folding of very long, flexible ssDNA.

We investigated the structure of a set of $\mathrm{Mg}_{2} \mathrm{PPi} / \mathrm{DNA}$ composites, where abundant $\mathrm{PPi}$ and $\mathrm{Mg}$ ions were precipitated in the presence of AmpDNA or $\lambda$ DNA in aqueous solution for $20 \mathrm{~h}$ by scanning electron microscopy (SEM) imaging. Following the previous studies, various concentrations of PPi $(0.5,1$, and $2 \mathrm{mM})$ were precipitated with a fixed amount of DNA $(4 \mu \mathrm{g})$ in the same buffer used in the RCA reaction. Parts a-c of Figure 1 show the influence of DNA molecules on the formation of the composites. First, $\mathrm{Mg}_{2} \mathrm{PPi}$ without DNA formed a random assembly comprising $1-2 \mu \mathrm{m}$ sized ellipsoidal nanoflakes in-plane. Some of these assembled into spherical or rodlike irregular aggregates with an increase in $\mathrm{Mg}_{2} \mathrm{PPi}$ concentration. In contrast, the inclusion of DNA led to the formation of relatively small, fairly uniform spherical particles with multipetal flower-like morphology similar to that of DNF. This also led to time-dependent crystallization with changes in size and morphology (Figure S5). We further analyzed a single ellipsoidal nanoflake by chemical mapping using a transmission electron microscope
(TEM) operating in scanning TEM (STEM) mode combined with energy dispersive X-ray spectroscopy (EDS) (Figure 1d). The STEM-EDS elemental maps confirmed the presence of $\mathrm{O}$, $\mathrm{Mg}$, and $\mathrm{P}$ in the nanoflake consisting of $\mathrm{Mg}_{2} \mathrm{PPi}$ (or $\left.\mathrm{Mg}_{2} \mathrm{P}_{2} \mathrm{O}_{7}\right)$.

As schematically depicted in Figure 1e, the presence of DNA molecules seems to have a significant effect on the formation of primary crystals and their growth. It is likely that the nucleation and crystal growth of $\mathrm{Mg}_{2} \mathrm{PPi}$ are retarded when the DNA molecules are present. This may be due to the electrostatic and van der Waals dispersion interactions between DNA and $\mathrm{Mg}^{2+}$ ions, ${ }^{24}$ effectively increasing the nucleation energy of $\mathrm{Mg}_{2} \mathrm{PPi}$ while also reducing the overall crystal growth rate, thus leading to much finer particles. This observation is in line with biomineralization processes finely regulated by naturally occurring organic macromolecules (e.g., complexes of nucleic acids, peptides, proteins, or lipids), which are believed to participate actively in the nucleation and growth processes. $^{25-27}$ The location of such organics can alter morphologies, structures, and orientations of the minerals via interactions with ionic precursors or mineral phases. Therefore, it is of great interest to understand how features such as size, morphology and crystal lattice can be affected by the DNA additives, acting as growth inhibitors and particle stabilizers during crystallization events.

We further performed a closer examination of single particles using both SEM and STEM. Using STEM, we can probe various aspects of a sample by collecting in parallel some of the multiple signals arising from interactions of the incident electron beam with a sample. Importantly, collecting the high angle annular dark field (HAADF) signal in the STEM 

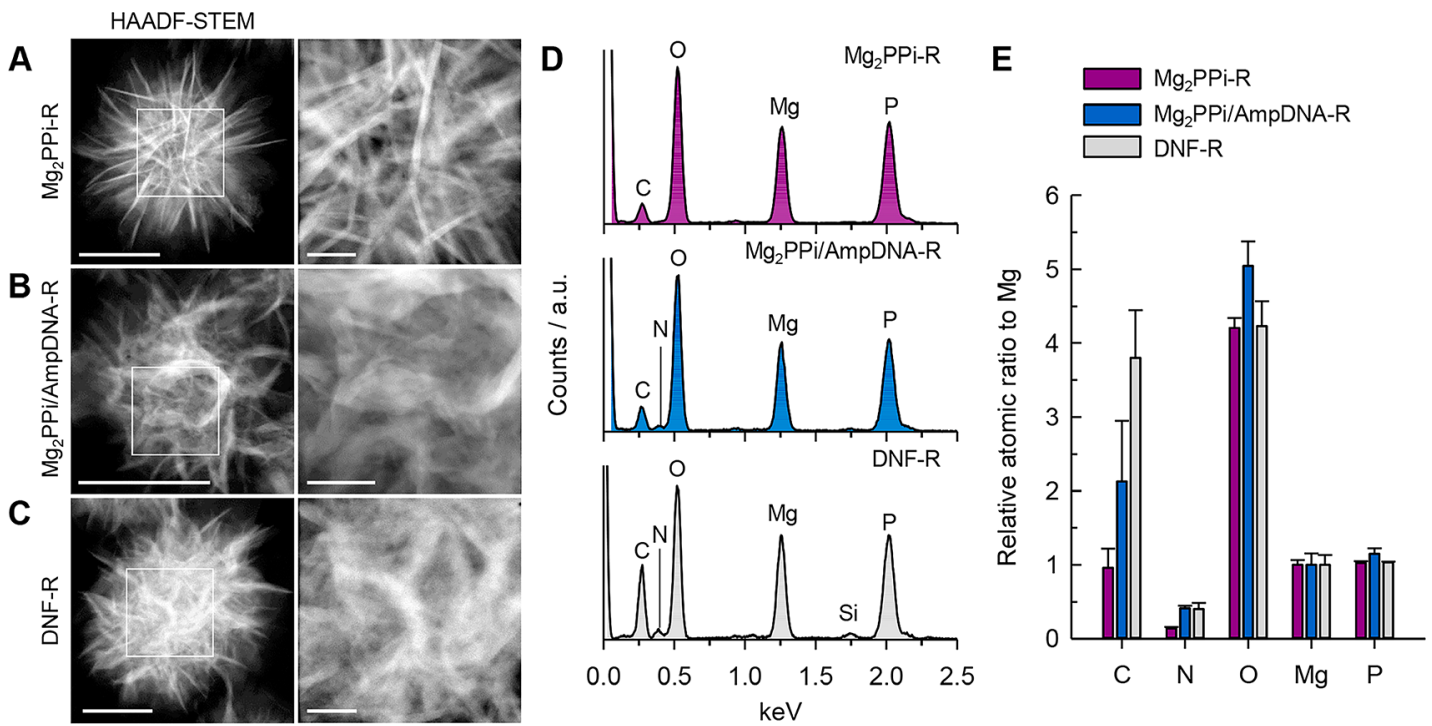

Figure 3. Structure and elemental composition of enzyme-included $\mathrm{Mg}_{2} \mathrm{PPi}$ composites. (A-C) Representative HAADF-STEM images of the $\mathrm{Mg}_{2} \mathrm{PPi}$ crystals precipitated in the presence of (A) RNase A and (B) RNase A and AmpDNA at $26.7 \mu \mathrm{g} \mathrm{mL}^{-1} \mathrm{DNA}^{2} 200 \mu \mathrm{g} \mathrm{mL} \mathrm{RNase}^{-1}$ and $2 \mathrm{mM} \mathrm{Mg}_{2} \mathrm{PPi}$. (C) In comparison, DNF-R was prepared through RCA reaction with the addition of RNase A. The particle regions from which the higher magnification images (right) originated are indicated by boxes on the lower magnification HAADF-STEM images (left). Scale bars, $500 \mathrm{~nm}$ (left) and $100 \mathrm{~nm}$ (right). (D) EDS spectra recorded from the whole area of the individual particle. (E) Relative atomic ratios of each element to $\mathrm{Mg}$ for each particle type. Data represent mean \pm s.d. of the EDS measurements determined over five particles.

produces an image where the image intensity (I) increases monotonically with specimen thickness and atomic number $(Z)$, where $I \sim Z^{\alpha}$ and $\alpha$ is a parameter between 1.6 and $2 .^{28-30}$ The resulting HAADF-STEM image contrast is therefore often referred to as "Z-contrast": a higher or lower contrast indicates, respectively, heavier (higher atomic number) or lighter elements (lower atomic number) in the specimen, i.e., for a uniform specimen thickness. As shown in Figure $\mathrm{S6}$, the $\mathrm{Mg}_{2} \mathrm{PPi}$ particles possessed more hierarchical structures with increasing concentrations of PPi ions, in which densely packed backbones with bright image contrast indicate the materials with a high elemental density, assumed to be inorganic materials comprising $\mathrm{O}(Z=8), \mathrm{Mg}(Z=12)$, and $\mathrm{P}$ $(Z=15)$.

Figure 2 shows high-resolution secondary electron SE-SEM and HAADF-STEM images of an individual particle of each formulation in conjunction with STEM-EDS analysis. Here we should note that we sought to find a single particle in $\mathrm{Mg}_{2} \mathrm{PPi}$ with similar morphology to other composites for comparison, although they typically form aggregates with random size and morphology. As shown in Figure 2a, the $\mathrm{Mg}_{2} \mathrm{PPi}$ particle exhibited a well-defined flower-like structure, consisting of several dozen nanoflakes with a smooth surface. The DNA-incorporated $\mathrm{Mg}_{2} \mathrm{PPi}$ particles also exhibited similar morphologies, but with more interconnected networks of nanoflakes, presumably connected by long DNA strands, as indicated by red arrows in the magnified views (Figure $2 b-d$ ). This is in good agreement with the HAADF-STEM images in Figure $2 \mathrm{e}-\mathrm{h}$. Notably, the observed inorganic backbones of the $\mathrm{Mg}_{2} \mathrm{PPi} / \mathrm{DNA}$ composites were nearly all curved with very few straight lines compared to $\mathrm{Mg}_{2} \mathrm{PPi}$ alone, implying that the adsorption of DNA led to anisotropic inhibition of the growth of the inorganic phases. EDS spectra were obtained from the entire region of an individual particle of each sample and revealed that $\mathrm{C}, \mathrm{N}, \mathrm{O}, \mathrm{Mg}$, and $\mathrm{P}$ are the main elements present in all $\mathrm{Mg}_{2} \mathrm{PPi} / \mathrm{DNA}$ composites (Figure 2i). The obtained EDS spectra were quantitatively analyzed with the
Inca software that uses calculated k-factors based on uniform composition and thickness of the specimen. Based on this quantitative analysis, the relative atomic ratios of $\mathrm{C} / \mathrm{Mg}, \mathrm{N} /$ $\mathrm{Mg}$, and $\mathrm{O} / \mathrm{Mg}$ in $\mathrm{Mg}_{2} \mathrm{PPi} / \mathrm{AmpDNA}, \mathrm{Mg}_{2} \mathrm{PPi} / \lambda \mathrm{DNA}$, and $\mathrm{DNF}$ were higher than those in $\mathrm{Mg}_{2} \mathrm{PPi}$. However, their $\mathrm{P} / \mathrm{Mg}$ ratios remained nearly the same, indicative of the incorporation of DNA within the particles (Figure 2j). We further confirmed the incorporation of DNA by performing AFM-based indentation experiments, showing a slightly decreased Young's modulus of ca. $3.5 \pm 0.6,6.0 \pm 0.8$, and $6.2 \pm 0.5 \mathrm{MPa}$ for $\mathrm{Mg}_{2} \mathrm{PPi} / \mathrm{AmpDNA}, \mathrm{Mg}_{2} \mathrm{PPi} / \lambda \mathrm{DNA}$, and DNF compared to bare $\mathrm{Mg}_{2} \mathrm{PPi}$ particles (ca. $7.8 \pm 2.0 \mathrm{MPa}$ ); thus, $\mathrm{Mg}_{2} \mathrm{PPi}$ crystals became slightly less stiff when DNA strands were present (not statistically significant).

We also investigated the effect of AmpDNA concentration on composite formation. The particle size gradually decreased with increasing AmpDNA concentration, forming relatively small particles of 500-600 nm in size for an AmpDNA concentration of $53 \mu \mathrm{g} \mathrm{mL}^{-1}$ (Figure S7). Experimentally, the addition of a higher concentration of AmpDNA ( $>53 \mu \mathrm{g}$ $\mathrm{mL}^{-1}$ ) slowed the nucleation and inhibited the growth of the $\mathrm{Mg}_{2} \mathrm{PPi}$ crystals such that any visible precipitates were not obtained after several washing steps. Therefore, these results suggest that the presence of DNA is of great importance for the spatial arrangement of inorganic $\mathrm{Mg}_{2} \mathrm{PPi}$ backbones in the structure and affects the particle size and distribution through strong association with $\mathrm{Mg}_{2} \mathrm{PPi}$ crystals. The length and structures of AmpDNA may also affect the crystallization of $\mathrm{Mg}_{2} \mathrm{PPi}$ since a DNA molecule carries different numbers of charged phosphate groups depending on size or along the ssDNA or dsDNA chain, ${ }^{31}$ which could influence the charge balance toward $\mathrm{Mg}^{2+}$. A more comprehensive understanding of the effect of AmpDNA with varying sizes on $\mathrm{Mg}_{2} \mathrm{PPi}$ formation could be achieved by tuning the RCA reaction time to produce smaller sized DNA products or by using other types of DNA, e.g., PCR products and short DNA oligonucleotides, smaller than AmpDNA in length. The structures of AmpDNA could be 
A

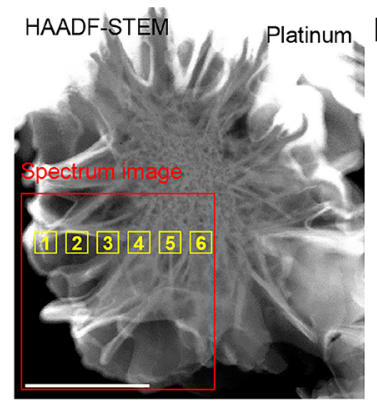

C

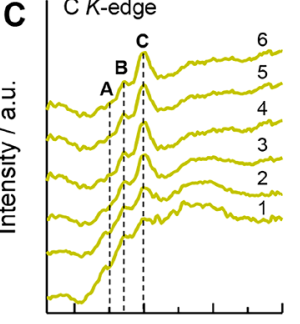

$\begin{array}{llll}280 & 290 & 300 & 310\end{array}$

Energy-loss / eV

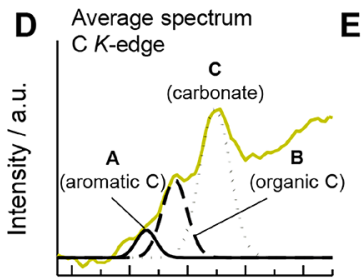

280284288292296

Energy-loss / eV

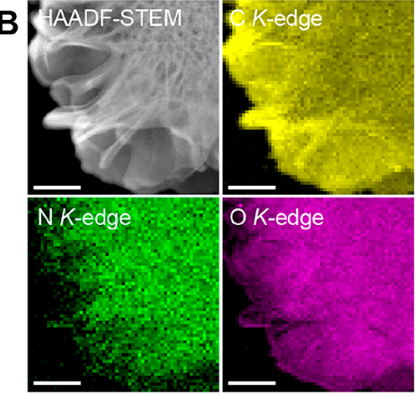

N K-edge

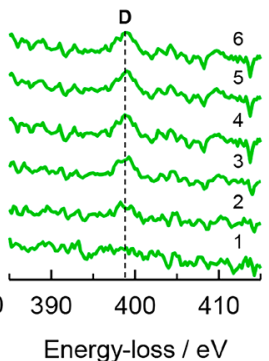

E
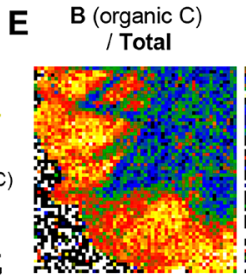

O K-edge

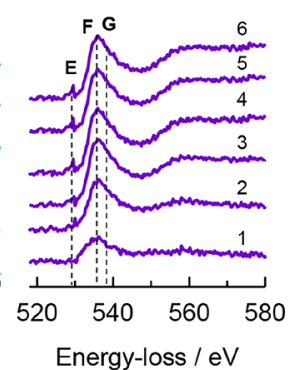

C (carbonate) / Total

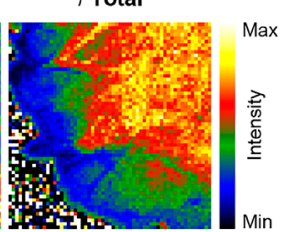

$\mathbf{F}$
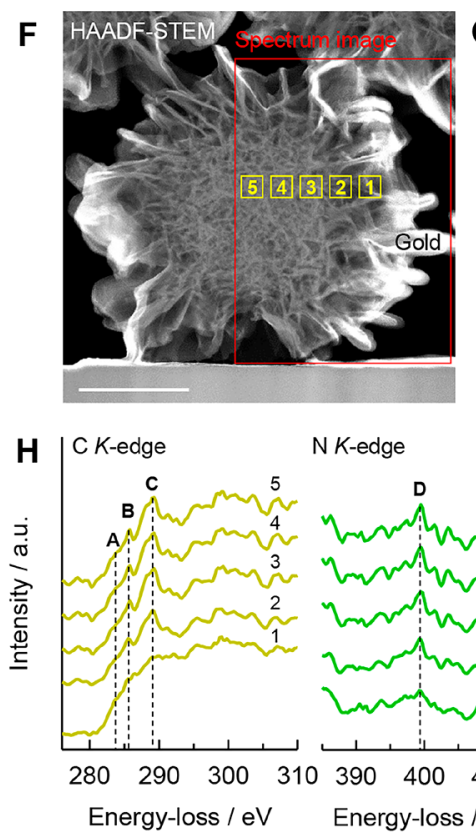

N K-edge

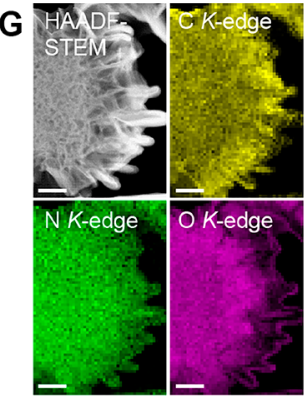

O K-edge

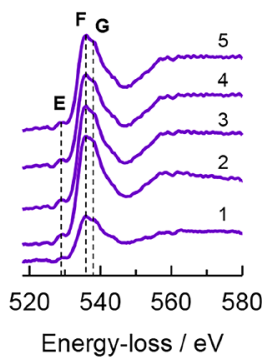

Average spectrum C K-edge

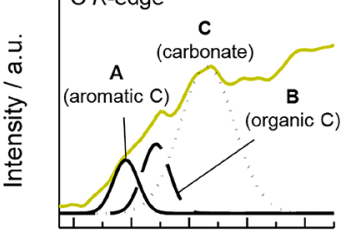

280284288292296

Energy-loss / eV

Figure 4. Spatially resolved STEM-EELS elemental analysis of (A-E) $\mathrm{Mg}_{2} \mathrm{PPi} / \mathrm{AmpDNA}-\mathrm{R}$ and (F-J) DNF-R. (A, F) Representative HAADF-STEM images of the lamellar $\mathrm{Mg}_{2} \mathrm{PPi} / \mathrm{AmpDNA}-\mathrm{R}$ and DNF-R specimens showing the highly porous interior. Scale bar, $500 \mathrm{~nm}$. (B, G) HAADF images and EELS elemental maps (with an 18-20 nm pixel size) extracted from the area marked as "spectrum image" in (A) and (F), displaying the distribution of carbon (C K-edge), nitrogen ( $\mathrm{N}$ K-edge), and oxygen (O K-edge). Scale bar, $200 \mathrm{~nm}$. (C, H) Evolution of $\mathrm{C} \mathrm{K}$-, $\mathrm{N} \mathrm{K}$-, and $\mathrm{O} \mathrm{K}$-EELS spectra recorded over an area of $5 \times 5$ pixels or $4 \times 4$ pixels from the regions numbered 1-6, as marked in (A) and (F). (D, I) Average C K-edge EELS spectra fitted with Gaussian peaks. Peaks A (284-285 eV), B (286-287 eV), and C $(289-290 \mathrm{eV}$ ) were assigned to aromatic carbon (aromatic C), organic carbon (organic $\mathrm{C}$ ), and carbonate bonding, respectively. (E, J) The ratio maps of peak $\mathrm{B}$, i.e., (organic $\mathrm{C}$ )/total intensity, and peak $\mathrm{C}$, i.e., (carbonate)/total intensity, show the relative contribution of organic carbon and carbonate bonding within the particle. Ratio maps were generated by dividing intensity maps of peak B (organic C) and C (carbonate), resulting from Gaussian fitting of $\mathrm{C} \mathrm{K}$-edges in (D) and (I), by the respective total C K-edge intensities (integrated over $15 \mathrm{eV}$ windows from the edge onsets).

potentially modulated using ssDNA-binding (SSB) proteins (e.g., T4 gene 32 protein, E. coli. SSB), which are known to stabilize ssDNA regions in a cooperative way and to enhance specific activity and yield of DNAP in DNA amplification applications. ${ }^{32}$ When introducing phage M13mp18 ssDNA as a control DNA, we observed that long ssDNA was effectively condensed with $\mathrm{Mg}_{2} \mathrm{PPi}$, leading to the formation of particles resembling $\mathrm{Mg}_{2} \mathrm{PPi} / \lambda$ DNA composites (Figure $\mathrm{S} 8$ ).

In addition to DNA, we further crystallized $\mathrm{Mg}_{2} \mathrm{PPi}$ in the presence of proteins with another organic additive, here RNase A $\left(200 \mu \mathrm{g} \mathrm{mL}{ }^{-1}\right)$, with or without AmpDNA (termed $\mathrm{Mg}_{2} \mathrm{PPi} / \mathrm{AmpDNA}-\mathrm{R}$ or $\mathrm{Mg}_{2} \mathrm{PPi}-\mathrm{R}$ ), and conducted identical analysis by STEM imaging and STEM-EDS. The protein additive yielded a similar particle morphology and configuration of the inorganic material as $\mathrm{Mg}_{2} \mathrm{PPi}$ and similarly exhibited more curved morphology of the inorganic backbone with the inclusion of DNA and enzymes (Figure $3 a-c$ ). The EDS data indicate that all enzyme-containing composites have slightly increased $\mathrm{O} / \mathrm{Mg}$ atomic ratios compared to the composites without the additional inclusion of enzymes (Figure 3d,e).

A direct observation of the spatial distribution of carbon and nitrogen provides a clear indication of organic materials such as DNA within the $\mathrm{Mg}_{2} \mathrm{PPi} / \mathrm{DNA}$ composites. The chemical bonding analysis of these two elements may offer some useful information on the molecular relationship between DNA and $\mathrm{Mg}_{2} \mathrm{PPi}$ matrix at the nanoscale. Although we observed the presence of both elements in all DNA-incorporated composites from the EDS analysis, mapping the elemental distribution within the particles with EDS is hampered by the technique's relatively low sensitivity to lighter elements such as $\mathrm{C}, \mathrm{N}$, and O. ${ }^{33}$ In contrast, electron energy loss spectroscopy (EELS) provides a higher sensitivity for lighter elements in combination with a much higher energy resolution, as compared to EDS. ${ }^{34,35}$ The higher energy resolution allows not only for elemental mapping but also for resolving spectral features in EELS ionization edges that can be attributed to specific chemical bonding states of the probed material down 

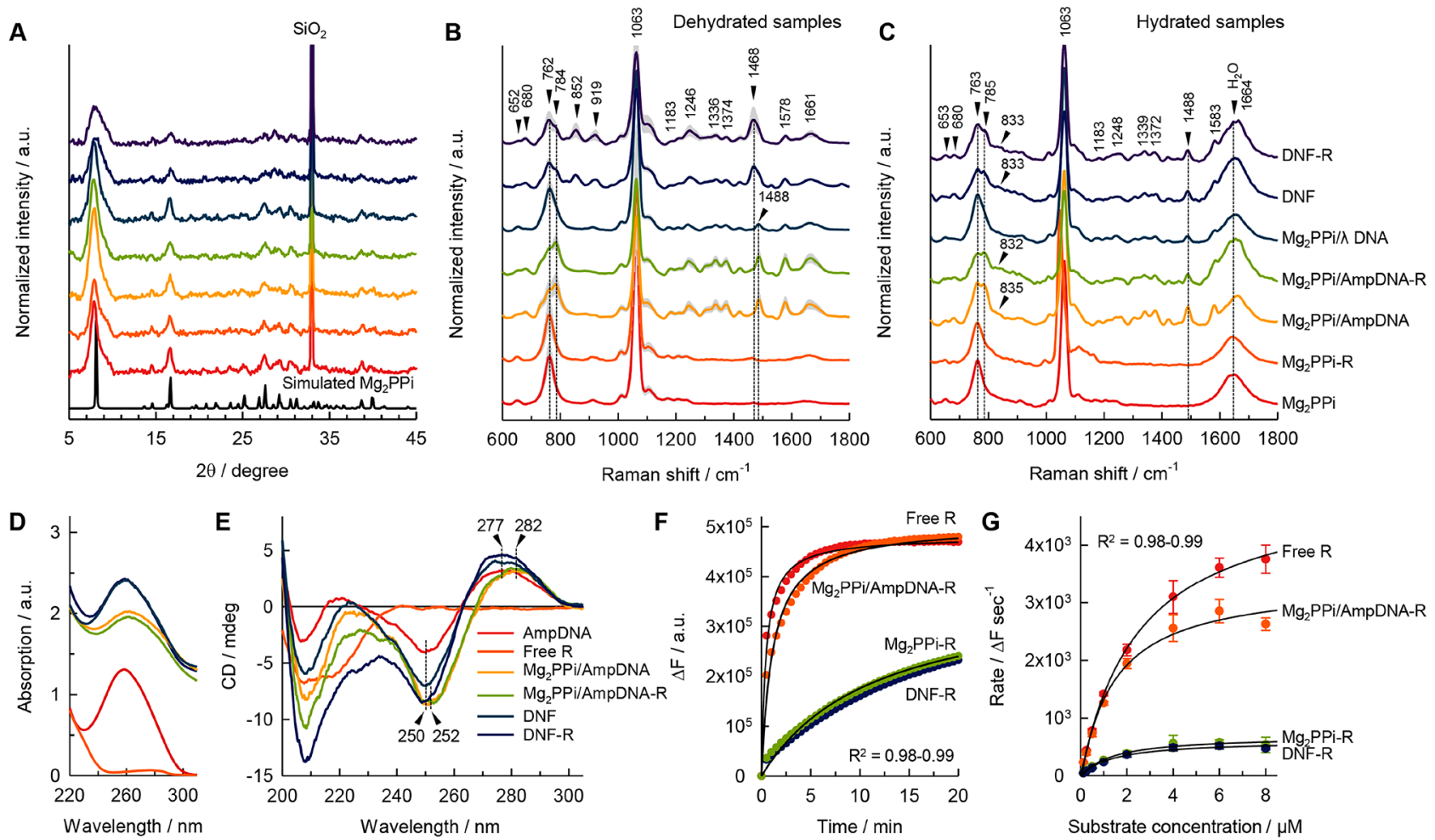

Figure 5. Effects of the inclusion of biomolecules on the growth of $\mathrm{Mg}_{2} \mathrm{PPi}$ crystals. (A) Powder XRD patterns and (B, C) Raman spectra of the $\mathrm{Mg}_{2} \mathrm{PPi}$ composites grown in the absence/presence of $\mathrm{DNA}$ and/or $\mathrm{RNase} \mathrm{A}\left(\mathrm{Mg}_{2} \mathrm{PPi}, \mathrm{Mg}_{2} \mathrm{PPi}-\mathrm{R}, \mathrm{Mg}_{2} \mathrm{PPi} / \mathrm{AmpDNA} \mathrm{Mg} \mathrm{g}_{2} \mathrm{PPi} /\right.$ AmpDNA-R, and $\mathrm{Mg}_{2} \mathrm{PPi} / \lambda$ DNA) and DNF in the absence/presence of RNase A (DNF and DNF-R). A diffraction pattern of the simulated $\mathrm{Mg}_{2} \mathrm{PPi}\left(\mathrm{Mg}_{2} \mathrm{P}_{2} \mathrm{O}_{7} \cdot 3.5 \mathrm{H}_{2} \mathrm{O}\right)$ is also shown. The Raman spectra were obtained in (B) dehydrated and (C) hydrated conditions using a $532 \mathrm{~nm}$ laser. In (B), the spectra were obtained with a laser power of $13 \mathrm{~mW}$ and acquisition time of $5 \mathrm{~s}$ and show the average spectra \pm s.d. of five different points in the sample area. In (C), the spectra were collected with a laser power of $30 \mathrm{~mW}$ and acquisition time of $20 \mathrm{~s}$ and show the spectra of one point in the sample area. All Raman spectra are normalized to the area under the curve. (D) UV absorption and (E) CD spectra of AmpDNA, free RNase A (free $\mathrm{R}$ ), $\mathrm{Mg}_{2} \mathrm{PPi} / \mathrm{AmpDNA}, \mathrm{Mg}_{2} \mathrm{PPi} / \mathrm{AmpDNA}-\mathrm{R}, \mathrm{DNF}$, and DNF-R. (F) Fluorescence intensity $(\Delta F=F$ $-F_{0}$, where $F$ and $F_{0}$ are the emitted fluorescence of a substrate with and without treatment of RNase-containing samples at $\lambda_{\mathrm{ex}}=490 \mathrm{~nm}$ and $\lambda_{\mathrm{em}}=520 \mathrm{~nm}$ ) as a function of time for four different catalytic systems. The concentration of RNA substrate was $4 \mu \mathrm{M}$. (G) Reaction rate against various concentrations of the substrate $(0.1-8 \mu \mathrm{M})$ for four catalytic systems. The concentration of RNase $A$ in each sample was $0.5 \mathrm{ng} \mathrm{mL} \mathrm{m}^{-1}$. Results represent mean \pm s.d. for four independent experiments.

to atomic spatial resolution ${ }^{36,37}$ and even of single atom defects. ${ }^{38}$ Therefore, to systematically study the localization of organics and their chemical bonding arrangements within the composites, we used EELS in a TEM (operating in STEM mode) on DNA, enzyme-embedded $\mathrm{Mg}_{2} \mathrm{PPi}$ composites $\left(\mathrm{Mg}_{2} \mathrm{PPi} / \mathrm{AmpDNA}-\mathrm{R}\right)$ and DNF-R.

For the EELS analysis, we prepared a site-specific lamellar sample with a thickness of $80-100 \mathrm{~nm}$ using the focused ion beam (FIB) lift-out technique (Figure S9). ${ }^{39,40}$ For EELS acquisition, we cooled down the sample to cryo-temperature $\left(-180{ }^{\circ} \mathrm{C}\right)$ inside the TEM using liquid nitrogen. Following this, we obtained the EEL spectral maps using raster scans with a $18-20 \mathrm{~nm}$ pixel size and denoised them using the principal component analysis (PCA) to enhance weak signals in the spectrum (see detailed procedures in the Materials and Methods). Figures 4 and S10 show the STEM and EELS characterization of the sliced sections of $\mathrm{Mg}_{2} \mathrm{PPi} / \mathrm{AmpDNA}-\mathrm{R}$ and DNF-R prepared by FIB. Maps of $\mathrm{C}, \mathrm{N}$, and $\mathrm{O}$ for both composites were generated from the corresponding absorption $K$-edges of $\mathrm{C}, \mathrm{N}$, and $\mathrm{O}$ in the EEL spectrum, which suggests that all elements of interest are present over the selected areas of the particles (Figure $4 \mathrm{~b}, \mathrm{~g}$ ).

The study of $\mathrm{C}$ and $\mathrm{N}$ K-edges was of particular interest to identify differences in specific chemical compositions between the two composites. Therefore, we first analyzed the fine structure of the $\mathrm{C} \mathrm{K}$-edge in various selected regions from the edge to center of the $\mathrm{Mg}_{2} \mathrm{PPi} / \mathrm{AmpDNA}-\mathrm{R}$ using Gaussian peak fitting. We assigned three peaks to three different atomic configurations: peak $\mathrm{A}$ at $\sim 285 \mathrm{eV}$ assigned to $1 \mathrm{~s}-\pi^{*}$ transitions in aromatic carbon bonds, peak B between 286 and $288 \mathrm{eV}$ attributable to $1 \mathrm{~s}-\pi^{*}$ transitions in organic carbon bonds (e.g., carbonly carbon groups in aromatic rings, aromatic carbon bonds attached to amide groups, carbonyl and pyrimidine carbon bonds, etc.), possibly from nucleic acids and proteins, and peak $\mathrm{C}$ at $\sim 290 \mathrm{eV}$ mainly corresponding to $1 s-\pi^{*}$ transitions in carbonate (Figure $\left.4 c, d\right) .{ }^{41-45}$ Specifically, the carbonate signal (peak $C$ ) was more pronounced in the center (EELS point 6 compared to point 1 in Figure 4a), while the organic carbon feature (peak B) was evenly preserved over the selected area of the particle. We observed the $\mathrm{N} \mathrm{K}$-edge at $\sim 399 \mathrm{eV}$ (peak D), most likely assigned to the $1 s-\pi^{*}$ transitions for nitrogen in an aromatic ring such as pyridine or amide group. ${ }^{43-45}$ However, as the intensity of $\mathrm{N} \mathrm{K}$-edge was weak due to low signal-to-noise, we could not resolve the fine structure of the $\mathrm{N} K$-edge.

The K-edges of carbon and nitrogen in the DNF-R were relatively similar in their dominant functional groups: particularly in the C K-edge, aromatic carbon bonds at $\sim 284$ 
$\mathrm{eV}$ (peak A), organic carbon bonds between 286 and $288 \mathrm{eV}$ (peak B), and carbonate at $\sim 289 \mathrm{eV}$ (peak C) (Figure 4h,i). We also obtained a reference spectrum from the platinumcovered region to evaluate if the observed peak features could be attributed to contamination during the sample preparation procedure (Figure S11). The C K-edge from the platinumcovered region showed a significant increase in the contribution of spectral features consistent with the $\sim 285 \mathrm{eV}$ $1 \mathrm{~s}-\pi^{*}$ and $\sim 292 \mathrm{eV} 1 \mathrm{~s}-\sigma^{*}$ peaks of amorphous and graphitic carbons, ${ }^{46}$ rather than an increase in the relative contribution of peaks $\mathrm{B}$ and $\mathrm{C}$. This confirmed that the $\mathrm{B}$ and $\mathrm{C}$ peaks are associated with organic and carbonate bonding inside the particle, rather than any superimposed carbon originating from the platinum deposition. Moreover, as indicated by the ratio maps of peaks $\mathrm{B}$ and $\mathrm{C}$ to the total $\mathrm{C} K$-edge intensity, both composites showed a relatively higher content of organic carbon bonding (peak B) at the edge of the particles compared to the central region, implying that organic materials such as DNA and enzymes are more likely to be localized on the periphery of the particles (Figure $4 \mathrm{e}, \mathrm{j}$ ).

The synthetic DNA-driven crystallization method provides a significant advantage for effective encapsulation of proteins of interest while not recruiting other enzymes (such as $\varphi 29$ DNAP, DNA ligase, and exonuclease) involved in the entire process of RCA-based DNF formulation. In this regard, we also speculated that the coincident participation of multiple proteins along with gradual elongation of DNA and production of $\mathrm{Mg}_{2} \mathrm{PPi}$ during $\mathrm{RCA}$ might give rise to a relatively lower level of DNA inclusion than the $\mathrm{Mg}_{2} \mathrm{PPi} / \mathrm{DNA}$ composites prepared by the coprecipitation route. To assess whether DNA molecules can alter the ordering of the $\mathrm{Mg}_{2} \mathrm{PPi}$ crystals by adhering to growing faces in different ways, the crystals grown in the absence or presence of DNA and/or enzymes were characterized by X-ray diffraction (XRD). The diffraction patterns of the composites clearly indicate that they exist in the phase of a hydrated magnesium pyrophosphate $\left(\mathrm{Mg}_{2} \mathrm{P}_{2} \mathrm{O}_{7}\right.$. $\left.3.5 \mathrm{H}_{2} \mathrm{O}\right) .{ }^{47}$ There are no pronounced shifts in the peak positions measured for either $\mathrm{Mg}_{2} \mathrm{PPi} / \mathrm{DNA}$ composites or DNF regardless of enzyme inclusion, as compared with pure $\mathrm{Mg}_{2} \mathrm{PPi}$ (Figure 5a). However, when DNA is introduced, they display peak broadening which spans the whole spectrum to some degree, ascribed to the inhomogeneous strain field caused by organic macromolecules as large entities within crystalline lattices, as reported in the literature. ${ }^{48}$

In order to ascertain how these DNA molecules are arranged in crystals, we further analyzed several $\mathrm{Mg}_{2} \mathrm{PPi}$ composites formed by two approaches and showed their Raman spectra of the $600-1800 \mathrm{~cm}^{-1}$ region with most prominent bands and their assignment (Figure 5b,c, Tables S4 and S5). Raman spectra provide clear evidence, in both types of composites $\left(\mathrm{Mg}_{2} \mathrm{PPi} / \mathrm{AmpDNA}\right.$ and DNF), of the inclusion of DNA from the peaks in the $1100-1700 \mathrm{~cm}^{-1}$ region predominantly originating from in-plane $\mathrm{C}-\mathrm{C}, \mathrm{C}-\mathrm{N}, \mathrm{C}=\mathrm{N}$ bond stretching or bending vibrations of nucleobases (Figure $5 \mathrm{~b}) .^{49-51}$ In contrast, RNase entrapment into the composites displayed no appreciable peak changes compared to those without RNase A. When DNA is incorporated into $\mathrm{Mg}_{2} \mathrm{PPi}$, the characteristic DNA shoulder peak at $\sim 784 \mathrm{~cm}^{-1}$ appears, attributed to the $\nu_{s}(\mathrm{OPO})$ vibration of DNA, whereas the peak at $762 \mathrm{~cm}^{-1}$ characteristic of the $\nu_{\mathrm{s}}(\mathrm{POP})$ vibration of PPi appears in all spectra. The $\nu_{\mathrm{s}}\left(\mathrm{PO}_{2}\right)$ tentatively assigned to the vibration band of DNA, normally at $1090 \mathrm{~cm}^{-1}$, is obscured by the strong $\nu_{\mathrm{s}}\left(\mathrm{PO}_{2}\right)$ vibration of PPi at $1063 \mathrm{~cm}^{-1}$ (Figure S13 and S14).
The intensity ratio $I_{784} / I_{762}$ or $I_{784} / I_{1063}$, which is indicative of the degree of covalency of the $\mathrm{C}-\mathrm{O}-\mathrm{P}-\mathrm{O}-\mathrm{C}$ bond of DNA phosphodiester backbones, ${ }^{51}$ increased in DNA-incorporated composites compared to $\mathrm{Mg}_{2} \mathrm{PPi}$ and showed a ca. 1.6-1.8fold higher level for $\mathrm{Mg}_{2} \mathrm{PPi} / \mathrm{AmpDNA}$ than for DNF (Figure S15a). This result implies that the synthetic DNA-directed crystallization approach gave rise to a relatively higher level of the $\mathrm{O}-\mathrm{P}-\mathrm{O}$ environments of DNA in the composites, compared to those synthesized via a RCA-based one-pot process.

The phosphate $\left(\mathrm{PO}_{2}\right)$ region of the spectrum centered at $1063 \mathrm{~cm}^{-1}$ contains more information about the effect of DNA on the structure of these $\mathrm{Mg}_{2} \mathrm{PPi}$ composites. The full width at half-maximum (fwhm) of the phosphate band, which can be related to phase crystallinity, ${ }^{52}$ further indicates that DNF exhibits a broader fwhm than $\mathrm{Mg}_{2} \mathrm{PPi}$ or $\mathrm{Mg}_{2} \mathrm{PPi} / \mathrm{AmpDNA}$ (Figure $\mathrm{S} 15 \mathrm{~b}$ ). This suggests a lower crystallinity of the $\mathrm{Mg}_{2} \mathrm{PPi}$ phase caused by impeded packing and organization of the crystals through interactions with DNA and proteins. This is consistent with XRD profiles observed in DNF and DNF-R, which may also point to a decrease of the interchain strength of crystals experienced by the adsorption of DNA and reaction proteins during the RCA process. This protein association during RCA is further supported by three intense peaks strikingly appearing at 852,919 , and $1468 \mathrm{~cm}^{-1}$ in the Raman spectra of DNA and DNF-R, which can be considered as protein peaks. ${ }^{53,54}$ More interestingly, these peaks nearly disappear when in aqueous solution (Figure 5c). Instead, an appearance of the broad peak around $832-835 \mathrm{~cm}^{-1}$, which is characteristic of B-DNA conformation, ${ }^{51}$ was detected in DNA-containing $\mathrm{Mg}_{2} \mathrm{PPi}$ composites. As noted in Figures 5c and $S 13 \mathrm{~b}$, this peak originated from the $\nu_{\mathrm{s}}(\mathrm{OPO})$ vibration of the polyphosphodiester bonds in DNA and was not clearly detected in the air-dried samples due to the conformational transition of some of the DNA from physiological B-DNA to dehydrated A-form DNA. ${ }^{55}$

The UV absorption and CD spectra in aqueous solution similarly reveal the DNA- $\mathrm{Mg}_{2} \mathrm{PPi}$ interaction. In Figure $5 \mathrm{~d}$,e, all composites except for $\mathrm{Mg}_{2} \mathrm{PPi}$ showed a maximum in absorbance near $260 \mathrm{~nm}$ and a positive band at $\sim 280 \mathrm{~nm}$ and a negative band at $\sim 250 \mathrm{~nm}$ in $\mathrm{CD}$ signals, indicating that the secondary structure of DNA is maintained in the B-form even after condensation with $\mathrm{Mg}_{2} \mathrm{PPi}^{56}$ However, we also note that $\mathrm{Mg}_{2} \mathrm{PPi} / \mathrm{AmpDNA}$ and $\mathrm{Mg}_{2} \mathrm{PPi} / \mathrm{AmpDNA}-\mathrm{R}$ displayed a positive signal at $283 \mathrm{~nm}$ and a negative signal at $255 \mathrm{~nm}$ in the CD spectra, which are slightly red-shifted in comparison to the peaks observed for free AmpDNA, DNF, and DNF-R. This shift is therefore likely caused by alterations in helical arrangements and the asymmetric phosphate backbone of DNA, known to be induced by strong interactions with other molecules, ${ }^{57}$ and here by $\mathrm{Mg}_{2} \mathrm{PPi}$, where we observed similar phenomena in their Raman spectra.

Finally, we investigated the catalytic activity of the RNase A embedded in $\mathrm{Mg}_{2} \mathrm{PPi} / \mathrm{AmpDNA}$ by monitoring the fluorescence of an RNA substrate labeled with a dye and quencher at the ends. The activity of free enzyme, $\mathrm{Mg}_{2} \mathrm{PPi}-\mathrm{R}$, and DNF-R was also studied for comparison (Figure 5f,g). Interestingly, the enzyme encapsulation in $\mathrm{Mg}_{2} \mathrm{PPi} / \mathrm{AmpDNA}$ was almost as effective in overall activity as free enzyme, while the enzyme within $\mathrm{Mg}_{2} \mathrm{PPi}$ or DNF exhibited ca. 2-fold lower activity at 20 $\min$ (Figure $5 \mathrm{f}$ ). Based on the initial rate (the maximum slope, $\mathrm{d} \Delta \mathrm{F} / \mathrm{d} t)$ at various substrate concentrations $(0.1-8 \mu \mathrm{M})$, we further calculated the $K_{\mathrm{m}}$ and $V_{\max }$ (kinetic parameters 
obtained from the Michaelis-Menten plot in Figure 5g) for each formulation. As reported in Table S6, the incorporated enzyme within the three composites gave negligible changes in the $K_{\mathrm{m}}$, while only $\mathrm{Mg}_{2} \mathrm{PPi} / \mathrm{AmpDNA}-\mathrm{R}$ showed a comparable $V_{\max }$ to free enzyme. This reveals that the DNA-mediated crystallization method leads to a more active catalyst than RCA-driven in situ synthesis, which accompanies other proteins and carryover reaction components. Moreover, $\mathrm{Mg}_{2} \mathrm{PPi} / \mathrm{AmpDNA}-\mathrm{R}$ yielded a ca. 5-fold higher $V_{\max }$ than that in $\mathrm{Mg}_{2} \mathrm{PPi}-\mathrm{R}$, consistent with the previous findings that highly ordered and hydrogen-bonded water environments of DNA structures in combination with high charge density are responsible for the enhancement of enzyme activity. ${ }^{58}$ Although the RCA-based one-pot approach provides experimental simplicity for enzyme encapsulation, it contains various possibilities of thermal, chemical, and/or physical denaturation of the embedded enzyme due to the reaction conditions (temperature, reaction buffers, other reaction enzymes) required for typical nucleic acid amplification techniques. Therefore, the synthetic DNA-driven crystallization method offers distinct advantages, namely enabling encapsulation of a diverse range of enzymes, favorable reaction conditions (room temperature and neutral $\mathrm{pH}$ ), and no nonselective association of other molecules.

\section{CONCLUSIONS}

In this work, we demonstrate an approach for controlling the size, structure, and properties of $\mathrm{Mg}_{2} \mathrm{PPi}$ crystals with well incorporated synthetic DNA molecules. In combination with our previous study on the fabrication of well-defined hybrid structures of $\mathrm{Mg}_{2} \mathrm{PPi} / \mathrm{DNA}$ composites through a one-pot enzymatic synthesis, we have shown that these composites can be formulated by precipitating abundant $\mathrm{Mg}$ and $\mathrm{PPi}$ ions with effectively isolated DNA, here AmpDNA, without association of nonselective adsorption of various proteins that can stem from the RCA reaction. As one of the key findings of our study, we report the influences of the inclusion of DNA as a macromolecular additive on the nucleation and growth kinetics, thereby controlling morphology and size of $\mathrm{Mg}_{2} \mathrm{PPi}$ crystals. The DNA inclusion gave rise to the formation of relatively uniform, spherical $\mathrm{Mg}_{2} \mathrm{PPi}$ /DNA particles with a more curved arrangement of inorganic phases, whereas $\mathrm{Mg}_{2} \mathrm{PPi}$ without DNA led to a random assembly of crystals with irregular size and morphology. From the diverse spectroscopic characterizations, we also found that $\mathrm{Mg}_{2} \mathrm{PPi}$ crystallization in the presence of DNA via the coprecipitation method led to the relatively higher crystallinity coupled with strong interaction with DNA compared to the RCA-based one-pot process. This denotes an alternative approach for RCA-driven protein encapsulation that is subjected to specific reaction conditions, such as temperature and reaction components, required for DNAP activity. Thus, our developed approach can be further extended to build protein-embedded DNA architectures using broad reaction conditions while taking advantage of the hydrated polymer-like DNA chains, demonstrating its potential as a biocatalytic enzyme complex. This approach exhibits great potential for even further biomedical applications, due to the ability to encapsulate a variety of biomolecules, such as proteins, DNA, and RNA.

\section{MATERIALS AND METHODS}

Preparation of AmpDNA. High-performance liquid chromatography purified DNA oligonucleotides (Integrated DNA Technology,
USA) were used without further purification (see Table S1 for details of DNA sequences). All enzymes and reagents used in rolling circle amplification (RCA) were obtained from New England Biolabs (USA). The amplified DNA (AmpDNA) was synthesized by carrying out the RCA reaction in the presence of pyrophosphatase (PPase) and subsequent purification with ethanol precipitation. To serve as a template for a typical RCA process, single-stranded DNA minicircles were first prepared by ligation of linear template DNA with T4 DNA ligase. Briefly, $5^{\prime}$-phosphorylated linear DNA $(5 \mu \mathrm{M})$ was hybridized with a primer $(10 \mu \mathrm{M})$ in ligase reaction buffer $(50 \mathrm{mM}$ Tris- $\mathrm{HCl}, 10$ $\mathrm{mM} \mathrm{MgCl}{ }_{2}, 1 \mathrm{mM}$ ATP, $10 \mathrm{mM} \mathrm{DTT}, \mathrm{pH} 7.5$ ) by heating at $95{ }^{\circ} \mathrm{C}$ for $5 \mathrm{~min}$ and slowly cooling to room temperature over $3 \mathrm{~h}$. The nick in the hybridized DNA was chemically sealed by incubation with T4 DNA ligase $\left(20 \mathrm{U} \mu \mathrm{L}^{-1}\right)$ in a reaction volume of $100 \mu \mathrm{L}$ at $16{ }^{\circ} \mathrm{C}$ overnight. After heat inactivation of the enzyme at $65^{\circ} \mathrm{C}$ for $10 \mathrm{~min}$, to degrade excess primers the resulting mixture was further treated with exonuclease I $\left(480 \mathrm{mU} \mu \mathrm{L}^{-1}\right)$ in reaction buffer $(67 \mathrm{mM}$ glycine- $\mathrm{KOH}, 6.7 \mathrm{mM} \mathrm{MgCl} 2,10 \mathrm{mM} \beta$-mercaptoethanol, $\mathrm{pH} 9.5$ ) at $37{ }^{\circ} \mathrm{C}$ for $1.5 \mathrm{~h}$ (final volume of $250 \mu \mathrm{L}$ ). The enzyme was inactivated at $80{ }^{\circ} \mathrm{C}$ for $15 \mathrm{~min}$. The resulting template DNA minicircle $(2 \mu \mathrm{M})$ containing T4 DNA ligase $\left(8 \mathrm{U}^{-1}\right)$ and exonuclease I $\left(480 \mathrm{mU} \mu \mathrm{L}^{-1}\right)$ was used for RCA reaction without further purification.

For synthesis of AmpDNA, a typical RCA mixture in a final volume of $50 \mu \mathrm{L}$ containing a DNA minicircle $(0.6 \mu \mathrm{M})$, dNTPs $(1 \mathrm{mM})$, phi29 DNA polymerase ( $\varphi 29$ DNAP, $\left.1 \mathrm{U} \mu \mathrm{L}^{-1}\right)$, and PPase $(2 \mathrm{mU}$ $\left.\mu \mathrm{L}^{-1}\right)$ was prepared in reaction buffer $(50 \mathrm{mM}$ Tris- $\mathrm{HCl}, 10 \mathrm{mM}$ $\mathrm{MgCl}_{2}, 10 \mathrm{mM}\left(\mathrm{NH}_{4}\right)_{2} \mathrm{SO}_{4}, 4 \mathrm{mM}$ DTT, $\mathrm{pH}$ 7.5). The reaction was performed at $30{ }^{\circ} \mathrm{C}$ for $20 \mathrm{~h}$ and terminated by inactivation of the DNAP at $65^{\circ} \mathrm{C}$ for $10 \mathrm{~min}$. It is important to note that relatively large amounts of DNA ligase $\left(120 \mathrm{U}, 2.4 \mathrm{U}_{\mu} \mathrm{L}^{-1}\right)$ and exonuclease $\mathrm{I}(7 \mathrm{U}$, $\left.144 \mathrm{mU} \mu \mathrm{L}^{-1}\right)$ still remained along with $50 \mathrm{U}$ of DNAP $\left(1 \mathrm{U} \mu \mathrm{L}^{-1}\right)$ in $50 \mu \mathrm{L}$ of RCA products. The RCA products were desalted and precipitated by ammonium acetate $(2.5 \mathrm{M})$ and ethanol. The DNA pellet was dissolved in $10 \mathrm{mM}$ Tris buffer ( $\mathrm{pH} \mathrm{8.0)}$ ), fully unfolded by heating at $95{ }^{\circ} \mathrm{C}$ for $10 \mathrm{~min}$, quenched on ice, and stored at $-20{ }^{\circ} \mathrm{C}$ for further use.

Here the obtained AmpDNA is highly likely to contain both singlestranded (ssDNA) and double-stranded DNA (dsDNA). However, it is not practically straightforward to quantify the exact amount of each ssDNA and dsDNA present in AmpDNA as currently available DNA quantification methods detect both DNA strands to some extent. Based on the results in Figure S3, we assumed that the amount of ssDNA in AmpDNA could be negligible, and therefore used the PicoGreen dsDNA reagent (Thermo Fisher Scientific, UK) for quantification. The fluorescence-based PicoGreen measurement enables the measurement of the concentration of dsDNA with varying fragment sizes and molecular complexity with reliable sensitivity and efficiency as compared with the UV absorbancebased method. ${ }^{59}$ The DNA concentration was then determined according to the manufacturer's protocols, based on the standard curve of serial dilutions of lambda DNA ( $\lambda$ DNA). The average repeating units in the resulting AmpDNA were estimated by following the previously reported methods (see detailed experimental procedures and analysis in Figure S4 and Table S3 in Supporting Information). ${ }^{17,60}$ The pyrophosphate $(\mathrm{PPi})$ concentration was assessed using the pyrophosphate assay kit (Abcam, UK) according to the manufacturer's protocols. The obtained values were inverted to PPi concentration using appropriate PPi standards.

Growth of $\mathrm{Mg}_{2} \mathrm{PPi}$ in the Presence of AmpDNA and RNase A. To formulate $\mathrm{Mg}_{2} \mathrm{PPi} / \mathrm{AmpDNA}$ and $\mathrm{Mg}_{2} \mathrm{PPi} / \mathrm{AmpDNA}-\mathrm{R}$, magnesium pyrophosphate $\left(\mathrm{Mg}_{2} \mathrm{PPi}\right.$ or $\left.\mathrm{Mg}_{2} \mathrm{P}_{2} \mathrm{O}_{7}\right)$ with varying concentrations $(0.5-2 \mathrm{mM})$ was precipitated in the presence of AmpDNA $\left(26.7 \mu \mathrm{g} \mathrm{mL}^{-1}\right)$ and/or RNase A $\left(200 \mu \mathrm{g} \mathrm{mL}^{-1}\right)$. A stock solution of sodium pyrophosphate decahydrate $\left(\mathrm{Na}_{4} \mathrm{P}_{2} \mathrm{O}_{7} \cdot 10 \mathrm{H}_{2} \mathrm{O}, 20\right.$ $\mathrm{mM}$, Sigma-Aldrich) dissolved in nuclease-free water was added to a solution of AmpDNA and/or RNase A in the RCA reaction buffer containing $10 \mathrm{mM} \mathrm{MgCl}$. Precipitation was allowed to proceed at 30 ${ }^{\circ} \mathrm{C}$. After $20 \mathrm{~h}$, white precipitates were visible and washed with nuclease-free water by centrifugation at $5000 \mathrm{~g}$ for $10 \mathrm{~min}$. The 
obtained particles were redispersed in nuclease-free water and kept at $4{ }^{\circ} \mathrm{C}$ until use. For comparison, $\mathrm{Mg}_{2} \mathrm{PPi} / \lambda$ DNA and $\mathrm{Mg}_{2} \mathrm{PPi} /$ M13mp18 ssDNA were was also formed by precipitating $\mathrm{Mg}_{2} \mathrm{PPi}$ in the presence of commercial lambda DNA ( $\lambda$ DNA, 26.7 and $40 \mu \mathrm{g}$ $\mathrm{mL}^{-1}$ ) and M13mp18 ssDNA (26.7 and $40 \mu \mathrm{g} \mathrm{mL}^{-1}$ ) obtained from New England Biolabs.

Synthesis of DNF and DNF-R. DNA flowers (DNF) and RNase A-entrapped DNF (DNF-R) were prepared using the one-pot process of RCA, as described in our previous work. ${ }^{8}$ For DNF-R, RNase A $\left(600 \mu \mathrm{g} \mathrm{mL}^{-1}\right)$ was additionally added to the RCA reaction mixture in a final volume of $50 \mu \mathrm{L}$ consisting of a DNA minicircle $(0.6 \mu \mathrm{M})$, dNTPs $(1 \mathrm{mM})$, and $\varphi 29$ DNAP $\left(1 \mathrm{U}_{\mu} \mathrm{L}^{-1}\right)$ in the RCA reaction buffer. The RCA was carried out at $30{ }^{\circ} \mathrm{C}$ for $20 \mathrm{~h}$, which is the same condition with the fabrication of $\mathrm{Mg}_{2} \mathrm{PPi} / \mathrm{DNA}$ composites and further incubated at $65{ }^{\circ} \mathrm{C}$ for $10 \mathrm{~min}$ to inactivate DNAP. The DNF and DNF-R were then collected by centrifugal separation and washing of the RCA products with nuclease-free water and stored at $4{ }^{\circ} \mathrm{C}$.

SEM Imaging. For scanning electron microscopy (SEM) imaging, $2.5 \mu \mathrm{L}$ of each sample solution in nuclease-free water was placed on a cleaned silicon wafer chip (about $5 \mathrm{~mm} \times 5 \mathrm{~mm}$ ) and air-dried at room temperature, followed by coating with $10 \mathrm{~nm}$ chromium in a Q150T S sputter coater (Quorum Technologies). SEM analysis was performed on a Leo Gemini 1525 FEG SEM equipped with a secondary electron in-lens detector operating at $5 \mathrm{kV}$.

Sample Preparation for TEM/STEM and EELS Analysis. The samples for TEM/STEM and EELS were prepared using a dual beam focused ion beam (FIB, FEI Helios NanoLab 600) (Figure S9). Briefly, a region of $14 \mu \mathrm{m} \times 2 \mu \mathrm{m}$ with particles of interest was selected in SEM mode and coated with $1 \mu \mathrm{m}$ electron deposited platinum at $5 \mathrm{kV}$. The region was further protected by $1 \mu \mathrm{m}$ platinum deposited by ion beam operating at $93 \mathrm{pA}, 30 \mathrm{kV}$. Two trenches of dimensions $18 \mu \mathrm{m} \times 4 \mu \mathrm{m} \times 4 \mu \mathrm{m}$ (length $\times$ width $\times$ depth) were made on either side of platinum protected layer using $2.8 \mathrm{nA}$ to 6.4 $\mathrm{nA}$ at $30 \mathrm{kV}$. The section was further thinned to $1 \mu \mathrm{m}$ and then released from the base using $6.4 \mathrm{nA}, 30 \mathrm{kV}$. The released sample was then lifted out using omniprobe manipulator and secured to a TEM lift-out 3 post copper grid (Agar Scientific) using platinum $(1 \mu \mathrm{m}$ thick). The sample section was further thinned down to approximately $80-100 \mathrm{~nm}$ thickness using currents in between 0.46 $\mathrm{nA}$ and $2.8 \mathrm{nA}, 30 \mathrm{kV}$. Finally, the surface of the sample was cleaned and polished using ion beam operated at $10 \mathrm{pA}, 2 \mathrm{kV}$ to remove possible artifacts introduced by the ion milling.

STEM Imaging and EDS Analysis. The samples were prepared by placing $10 \mu \mathrm{L}$ of the sample solution on 200 -mesh carbon-coated $\mathrm{Cu}$ grids (Electron Microscopy Science, USA). Imaging in scanning transmission microscopy (STEM) mode and energy dispersive X-ray spectroscopy (EDS) analysis were performed on a JEOL JEM-2100F TEM operating at $200 \mathrm{kV}$, equipped with Gatan Orius SC $1000(2 \mathrm{k}$ $\times 4 \mathrm{k})$, Gatan high-angle annular dark-field (HAADF), Gatan annular bright field (BF), and EDS detectors (Oxford Instruments INCA EDS $80 \mathrm{~mm}$ X-Max detector system with STEM capability). The EDS spectra from the whole area of the individual particles were taken. Measurements over five particles per sample were used for elemental analysis. The obtained EDS spectra were quantitatively analyzed with a standardless approach and $k$-factors provided by the Inca software (Oxford Instruments).

EELS Acquisition and Analysis. For EELS acquisition, the FIB prepared sample was cooled down to cryo-temperature $\left(-180{ }^{\circ} \mathrm{C}\right)$ using liquid nitrogen in the cryo-sample holder inside the TEM. The EELS was performed on a JEOL JEM-2100F TEM in STEM mode at $200 \mathrm{kV}$, equipped with STEM detectors (HAADF/BF), Gatan Quantum SE energy filter, and Gatan Orius SC $1000(2 \mathrm{k} \times 4 \mathrm{k})$ camera. The spectral maps were collected with an energy resolution of $\sim 1 \mathrm{eV}$ and using a dispersion of $0.25 \mathrm{eV} /$ channel. The exposure time was set to $0.5-1.0 \mathrm{~s}$, and spectra were acquired every $18-20 \mathrm{~nm}$ following $2 \mathrm{D}$ raster scans. The spatial drift was corrected in parallel, and high quality (HQ) dark correction was applied following the acquisition of EEL spectrum images.

For EELS analysis, principal component analysis (PCA) based denoising was performed as implemented in the Multivariate
Statistical Analysis (MSA) plugin for Gatan's DigitalMicrograph software 1.8 (commercially available from HREM Research Inc.). The 25 or 13 most significant components were included for reconstruction of the data sets used for the EELS analysis of $\mathrm{Mg}_{2} \mathrm{PPi} / \mathrm{AmpDNA}-\mathrm{R}$ and DNF-R, respectively. The spectral maps were calibrated using the $\mathrm{O} K$-edge at $536 \mathrm{eV}$. A power law background subtraction with a $10-20 \mathrm{eV}$ window or wider was performed on all acquired edges. For carbon $K$ - (C $K$-), nitrogen $K$ $(\mathrm{N} \mathrm{K}-)$, and oxygen $\mathrm{K}$ - ( $\mathrm{O} \mathrm{K}$-) edges, the fitting windows were set at 265-282, 379-394, and 509-525 eV, respectively. To obtain elemental maps, the $\mathrm{C}, \mathrm{N}$, and $\mathrm{O}$ signals are integrated over the following energy windows: 284-291 eV (C K), 397-402 eV (N K), and $528-544 \mathrm{eV}(\mathrm{O} \mathrm{K})$. To quantify spectral peak properties, the $\mathrm{C}$ $\mathrm{K}$-edge was fitted with Gaussian functions using the nonlinear leastsquares (NLLS) fitting tool available within DigitalMicrograph software 1.8 and subsequently plotted using SigmaPlot 12.0 (Systat Software Inc.). Ratio maps where created by dividing intensity maps of peaks $\mathrm{B}$ and $\mathrm{C}$ (resulting from the Gaussian fitting of the data set, using peaks centered at 284-285 (A), 286-287 (B), and 289-290 $\mathrm{eV}(\mathrm{C})$ ) by the total $\mathrm{C}$ K-edge intensity integrated over a $15 \mathrm{eV}$ window from the edge onset (at $283 \mathrm{eV}$ for $\mathrm{Mg}_{2} \mathrm{PPi} / \mathrm{AmpDNA}-\mathrm{R}$ and at $281 \mathrm{eV}$ for DNF-R). The peaks were assigned using the available XANES and EELS literature. ${ }^{44,45,61-64}$

XRD Measurements. For X-ray diffraction (XRD) measurements, the sample films on an oxygen plasma-treated silicon wafer chip (about $1 \mathrm{~cm} \times 1 \mathrm{~cm}$ ) were prepared by evaporation of aqueous sample solution in air. Diffraction patterns of the sample films were recorded on a PANalytical X'Pert Pro MPD (PANalytical, The Netherlands) using $\mathrm{Cu} \mathrm{K} \alpha$ radiation $(\lambda=1.54 \AA$, $40 \mathrm{kV}, 40 \mathrm{~mA})$. The data were collected at angles from $5^{\circ}$ to $60^{\circ}$ with a step size of $0.03^{\circ}$, and a scan rate of $2^{\circ} \mathrm{min}^{-1}$. The obtained results were analyzed using X’Pert HighScore Plus software.

Raman Spectroscopy Analysis. The sample solution dispersed in nuclease-free water was dropped onto a cleaned calcium fluoride Raman substrate (Crystran Ltd., UK) and air-dried overnight. For comparison, a droplet of the sample solution was placed on the substrate just before Raman measurements. Analysis was performed on a confocal Raman microspectroscopy system (alpha $300 \mathrm{R}+$, WITec GmbH, Germany) using a green laser $\left(\lambda_{\text {ex }}=532 \mathrm{~nm}\right)$ with maximum output of $75 \mathrm{~mW}$ and a $\times 20 / 0.4 \mathrm{NA}$ microscope objective lens (EC Epiplan, Zeiss, Germany). The backscattered Raman signals were directed to the spectrometer using a $100 \mu \mathrm{m}$ low $\mathrm{OH}$ silicon fiber, equipped with a thermoelectrically cooled, charge-coupled device camera (Newton, Andor Technology Ltd., UK). Raman spectra were collected in the spectral range from 0 to $3,600 \mathrm{~cm}^{-1}$ under a laser power of $\sim 13 \mathrm{~mW}$ with an acquisition time of $5 \mathrm{~s}$ (for solid samples) and $\sim 30 \mathrm{~mW}$ with an acquisition time of $20 \mathrm{~s}$ (for liquid samples).

Raman data were processed using in-house written methods using MATLAB software (MathWorks Inc., USA). The data were first smoothed using the second-order Savitsky-Golay method with a window size of 9 . For the baseline correction, a second-order polynomial was fitted to the smoothed spectrum in the range of 600$1800 \mathrm{~cm}^{-1}$ and subtracted. All of the spectra presented were subsequently normalized to the area under the curve, which removed any instrument effects and enabled comparisons between the samples by reducing the signal intensity variability. To determine the full width at half-maximum (fwhm), the peak centered at $1063 \mathrm{~cm}^{-1}$ in the $1020-1110 \mathrm{~cm}^{-1}$ spectral region was fit to a Gaussian profile using OriginPro 9.1 software. The peaks were assigned according to the literature data. ${ }^{49-51,53-55}$

UV Absorption and CD Measurements. The samples were redispersed in $10 \mathrm{mM}$ Tris buffer ( $\mathrm{pH} 8.0)$. The UV absorption and circular dichroism (CD) signals were recorded on a PerkinElmer Lambda $25 \mathrm{UV} /$ vis spectrometer in a $1.0 \mathrm{~cm}$ quartz cuvette and JASCO J-715 spectrometer in a $0.1 \mathrm{~cm}$ quartz cuvette, respectively. The CD data were collected at room temperature with two scan accumulations at a scan rate of $50 \mathrm{~nm} \mathrm{~min}^{-1}$ with a $0.1 \mathrm{~nm}$ pitch and 4 $s$ integration time. 
RNase Activity Test. The ribonucleotic activity of RNase A was evaluated using a synthetic RNA oligonucleotide, which has a fluorescein dye and quencher at both ends (RNase Alert substrate, Integrated DNA Technology). Before testing, the protein concentration of each sample was measured by Qubit protein reagent (Thermo Fisher Scientific), based on the standard curve using free RNase A with known concentrations (0, 200, and $\left.400 \mathrm{ng} \mu \mathrm{L}^{-1}\right)$. Protein-containing sample solution $(10 \mu \mathrm{L})$ was mixed with $190 \mu \mathrm{L}$ of Qubit working solution prepared by diluting 200-fold the Qubit protein reagent in assay buffer according to the manufacturer's instructions. After incubation at room temperature for $15 \mathrm{~min}$, the fluorescence was measured with the Qubit 2.0 fluorometer. The amount of encapsulated RNase A in DNF-R was calculated by subtracting the measured concentration in DNF as a blank sample (which possibly entraps other proteins such as DNAP, ligase, or exonuclease) from that in DNF-R. Given that there are no proteins associated during particle formation, the measured concentrations of $\mathrm{Mg}_{2} \mathrm{PPi}-\mathrm{R}$ and $\mathrm{Mg}_{2} \mathrm{PPi} / \mathrm{AmpDNA}-\mathrm{R}$ were used without subtraction of a blank sample, here, $\mathrm{Mg}_{2} \mathrm{PPi}$. RNase activity assays were performed at room temperature by adding $10 \mu \mathrm{L}$ of the RNase Alert substrate with an increasing concentration $(0.1-8 \mu \mathrm{M})$ to $90 \mu \mathrm{L}$ of each sample with an enzyme concentration of $0.5 \mathrm{ng} \mathrm{mL}^{-1}$. Tris buffer (50 $\mathrm{mM}, \mathrm{pH} 8.0$ ) was used as an assay buffer. The fluorescence intensity at an excitation of $490 \mathrm{~nm}$ and an emission of $520 \mathrm{~nm}$ was monitored for 30 min using the EnVision multilabel plate reader (PerkinElmer, USA). The $K_{\mathrm{m}}$ and $V_{\max }$ were extracted from the Michaelis-Menten and Lineweaver-Burk plots (Figure $5 \mathrm{~g}$ and S16), based on the following equation: $1 / \mathrm{V}=\left(K_{\mathrm{m}} / V_{\max }\right) \times[\mathrm{S}]+1 / V_{\max }$, where $V$ is the initial catalytic rate, $K_{\mathrm{m}}$ is the Michaelis-Menten constant, $V_{\max }$ is the maximum catalytic rate, and $[S]$ is the substrate concentration. The initial rate of the enzyme was obtained by measuring a change in fluorescence intensity of the sample and substrate over time, as shown in Figure 5f.

\section{ASSOCIATED CONTENT}

\section{S Supporting Information}

The Supporting Information is available free of charge on the ACS Publications website at DOI: 10.1021/acsnano.8b06492.

Details of experiments (gel electrophoresis, AFM imaging and indentation, analysis of AmpDNA with nucleases and SYBR dyes, SIM imaging), additional notes, figures, and tables, including characterization of AmpDNA, HAADF-STEM images of a single $\mathrm{Mg}_{2} \mathrm{PPi}$ particle, SE-SEM images and size distribution of various $\mathrm{Mg}_{2} \mathrm{PPi} / \mathrm{DNA}$ composites, time-dependent formation of $\mathrm{Mg}_{2} \mathrm{PPi} / \mathrm{AmpDNA}$, the FIB lift-out technique procedures, HAADF-STEM images of the lamellar specimens prepared by the FIB, EELS reference spectrum from the platinum region, SIM imaging and Raman spectra analysis of various $\mathrm{Mg}_{2} \mathrm{PPi}$ composites, and tables of nucleic acid sequences, nuclease properties, estimated average repeating units in AmpDNA, tentative Raman band assignment, and enzyme kinetics of various $\mathrm{Mg}_{2} \mathrm{PPi}$ composites (PDF)

\section{AUTHOR INFORMATION}

\section{Corresponding Author}

*E-mail: m.stevens@imperial.ac.uk.

\section{ORCID}

Eunjung Kim: 0000-0001-9579-9414

Molly M. Stevens: 0000-0002-7335-266X

Notes

The authors declare no competing financial interest.

\section{ACKNOWLEDGMENTS}

E.K. acknowledges support from Basic Science Research Program through the National Research Foundation of Korea (NRF) funded by the Ministry of Education (2015R1A6A3A03018919). A.G. acknowledges support from the European Union's Horizon 2020 Research and Innovation Programme through the Marie Skłodowska-Curie Individual Fellowship "RAISED” under Grant Agreement No. 660757. M.M.S. acknowledges support from the ERC Seventh Framework Programme Consolidator grant "Naturale CG" (616417), the EPSRC grant "Biofunctionalized nanomaterials for ultrasensitive biosensing" (EP/K020641/1), the Wellcome Trust Senior Investigator Award $(098411 / \mathrm{Z} / 12 / \mathrm{Z})$, and isense EPSRC IRC in Early Warning Sensing Systems for Infectious Diseases (EP/K031953/1). We thank Dr. M. S. Bergholt for the critical reading of this manuscript and insightful comments and the Harvey Flower Electron Microscopy Suite at Imperial College London for support with SEM and TEM characterization. SIM imaging was performed in the Facility for Imaging by Light Microscopy (FILM) and is partly supported by the BBSRC (BB/L015129/ 1). The SuperSTEM Laboratory is the U.K. National Research Facility for Advanced Electron Microscopy, supported by the Engineering and Physical Sciences Research Council (EPSRC). Raw data are available at DOI:10.5281/zenodo. 2560145 .

\section{REFERENCES}

(1) Heuer, A. H.; Fink, D. J.; Laraia, V. J.; Arias, J. L.; Calvert, P. D.; Kendall, K.; Messing, G. L.; Blackwell, J.; Rieke, P. C.; Thompson, D. H.; Wheeler, A. P.; Veis, A.; Caplan, A. I. Innovative Materials Processing Strategies: A Biomimetic Approach. Science 1992, 255, 1098-1105.

(2) Mann, S.; Archibald, D. D.; Didymus, J. M.; Douglas, T.; Heywood, B. R.; Meldrum, F. C.; Reeves, N. J. Crystallization at Inorganic-Organic Interfaces: Biominerals and Biomimetic Synthesis. Science 1993, 261, 1286-1292.

(3) Song, R.-Q.; Colfen, H. Additive Controlled Crystallization. CrystEngComm 2011, 13, 1249-1276.

(4) Lee, J. B.; Hong, J.; Bonner, D. K.; Poon, Z.; Hammond, P. T. Self-Assembled RNA Interference Microsponges for Efficient siRNA Delivery. Nat. Mater. 2012, 11, 316-322.

(5) Zhu, G.; Hu, R.; Zhao, Z.; Chen, Z.; Zhang, X.; Tan, W. Noncanonical Self-Assembly of Multifunctional DNA Nanoflowers for Biomedical Applications. J. Am. Chem. Soc. 2013, 135, 1643816445.

(6) Hu, R.; Zhang, X.; Zhao, Z.; Zhu, G.; Chen, T.; Fu, T.; Tan, W. DNA Nanoflowers for Multiplexed Cellular Imaging and Traceable Targeted Drug Delivery. Angew. Chem., Int. Ed. 2014, 53, 5821-5826.

(7) Shopsowitz, K. E.; Roh, Y. H.; Deng, Z. J.; Morton, S. W.; Hammond, P. T. RNAi-Microsponges Form Through Self-Assembly of the Organic and Inorganic Products of Transcription. Small 2014, 10, 1623-1633.

(8) Kim, E.; Zwi-Dantsis, L.; Reznikov, N.; Hansel, C. S.; Agarwal, S.; Stevens, M. M. One-Pot Synthesis of Multiple ProteinEncapsulated DNA Flowers and Their Application in Intracellular Protein Delivery. Adv. Mater. 2017, 29, 1701086.

(9) Sun, W.; Jiang, T.; Lu, Y.; Reiff, M.; Mo, R.; Gu, Z. Cocoon-Like Self-Degradable DNA Nanoclew for Anticancer Drug Delivery. J. Am. Chem. Soc. 2014, 136, 14722-14725.

(10) Jang, M.; Kim, J. H.; Nam, H. Y.; Kwon, I. C.; Ahn, H. J. Design of a Platform Technology for Systemic Delivery of siRNA to Tumours Using Rolling Circle Transcription. Nat. Commun. 2015, 6, 7930.

(11) Sun, W.; Ji, W.; Hall, J. M.; Hu, Q.; Wang, C.; Beisel, C. L.; Gu, Z. Self-Assembled DNA Nanoclews for the Efficient Delivery of 
CRISPR-Cas9 for Genome Editing. Angew. Chem., Int. Ed. 2015, 54, 12029-12033.

(12) Wang, C.; Sun, W.; Wright, G.; Wang, A. Z.; Gu, Z. Inflammation-Triggered Cancer Immunotherapy by Programmed Delivery of CpG and Anti-PD1 Antibody. Adv. Mater. 2016, 28, 8912-8920.

(13) Zhu, G.; Mei, L.; Vishwasrao, H. D.; Jacobson, O.; Wang, Z.; Liu, Y.; Yung, B. C.; Fu, X.; Jin, A.; Niu, G.; Wang, Q.; Zhang, F.; Shroff, H.; Chen, X. Intertwining DNA-RNA Nanocapsules Loaded with Tumor Neoantigens as Synergistic Nanovaccines for Cancer Immunotherapy. Nat. Commun. 2017, 8, 1482.

(14) Merindol, R.; Loescher, S.; Samanta, A.; Walther, A. PathwayControlled Formation of Mesostructured All-DNA Colloids and Superstructures. Nat. Nanotechnol. 2018, 13, 730-738.

(15) Ni, Q.; Zhang, F.; Zhang, Y.; Zhu, G.; Wang, Z.; Teng, Z.; Wang, C.; Yung, B. C.; Niu, G.; Lu, G.; Zhang, L.; Chen, X. In Situ shRNA Synthesis on DNA-Polylactide Nanoparticles to Treat Multidrug Resistant Breast Cancer. Adv. Mater. 2018, 30, 1705737.

(16) Yuan, X.; Xiao, F.; Zhao, H.; Huang, Y.; Shao, C.; Weizmann, Y.; Tian, L. High-Yield Method To Fabricate and Functionalize DNA Nanoparticles from the Products of Rolling Circle Amplification. ACS Appl. Bio Mater. 2018, 1, 511-519.

(17) Liu, M.; Zhang, Q.; Kannan, B.; Botton, G. A.; Yang, J.; Soleymani, L.; Brennan, J. D.; Li, Y. Self-Assembled Functional DNA Superstructures as High-Density and Versatile Recognition Elements for Printed Paper Sensors. Angew. Chem., Int. Ed. 2018, 57, 1244012443.

(18) Baker, Y. R.; Chen, J.; Brown, J.; El-Sagheer, A. H.; Wiseman, P.; Johnson, E.; Goddard, P.; Brown, T. Preparation and Characterization of Manganese, Cobalt and Zinc DNA Nanoflowers with Tuneable Morphology, DNA Content and Size. Nucleic Acids Res. 2018, 46, 7495-7505.

(19) Gallagher-Jones, M.; Bessho, Y.; Kim, S.; Park, J.; Kim, S.; Nam, D.; Kim, C.; Kim, Y.; Noh, D. Y.; Miyashita, O.; Tama, F.; Joti, Y.; Kameshima, T.; Hatsui, T.; Tono, K.; Kohmura, Y.; Yabashi, M.; Hasnain, S. S.; Ishikawa, T.; Song, C. Macromolecular Structures Probed by Combining Single-Shot Free-Electron Laser Diffraction with Synchrotron Coherent X-Ray Imaging. Nat. Commun. 2014, 5, 3798.

(20) Akama, S.; Yamamura, M.; Kigawa, T. A Multiphysics Model of In Vitro Transcription Coupling Enzymatic Reaction and Precipitation Formation. Biophys. J. 2012, 102, 221-230.

(21) Dean, F. B.; Nelson, J. R.; Giesler, T. L.; Lasken, R. S. Rapid Amplification of Plasmid and Phage DNA Using Phi29 DNA Polymerase and Multiply-Primed Rolling Circle Amplification. Genome Res. 2001, 11, 1095-1099.

(22) Mori, Y.; Nagamine, K.; Tomita, N.; Notomi, T. Detection of Loop-Mediated Isothermal Amplification Reaction by Turbidity Derived from Magnesium Pyrophosphate Formation. Biochem. Biophys. Res. Commun. 2001, 289, 150-154.

(23) Ali, M. M.; Li, F.; Zhang, Z.; Zhang, K.; Kang, D.-K.; Ankrum, J. A.; Le, X. C.; Zhao, W. Rolling Circle Amplification: A Versatile Tool for Chemical Biology, Materials Science and Medicine. Chem. Soc. Rev. 2014, 43, 3324-3341.

(24) Li, W.; Nordenskiöld, L.; Mu, Y. Sequence-Specific Mg2+DNA Interactions: A Molecular Dynamics Simulation Study. J. Phys. Chem. B 2011, 115, 14713-14720.

(25) Mann, S. Molecular Tectonics in Biomineralization and Biomimetic Materials Chemistry. Nature 1993, 365, 499-505.

(26) Meldrum, F. C.; Cölfen, H. Controlling Mineral Morphologies and Structures in Biological and Synthetic Systems. Chem. Rev. 2008, 108, 4332-4432.

(27) Sotiropoulou, S.; Sierra-Sastre, Y.; Mark, S. S.; Batt, C. A. Biotemplated Nanostructured Materials. Chem. Mater. 2008, 20, 821834.

(28) Midgley, P. A.; Weyland, M. 3D Electron Microscopy in the Physical Sciences: the Development of Z-Contrast and EFTEM Tomography. Ultramicroscopy 2003, 96, 413-431.
(29) Thomas, J. M.; Midgley, P. A.; Yates, T. J. V.; Barnard, J. S.; Raja, R.; Arslan, I.; Weyland, M. The Chemical Application of HighResolution Electron Tomography: Bright Field or Dark Field? Angew. Chem., Int. Ed. 2004, 43, 6745-6747.

(30) Midgley, P. A.; Dunin-Borkowski, R. E. Electron Tomography and Holography in Materials Science. Nat. Mater. 2009, 8, 271-280.

(31) Zhang, Y.; Zhou, H.; Ou-Yang, Z.-C. Stretching SingleStranded DNA: Interplay of Electrostatic, Base-Pairing, and Base-Pair Stacking Interactions. Biophys. J. 2001, 81, 1133-1143.

(32) Chase, J. W.; Williams, K. R. Single-Stranded DNA Binding Proteins Required for DNA Replication. Annu. Rev. Biochem. 1986, 55, 103-136.

(33) Lugg, N. R.; Kothleitner, G.; Shibata, N.; Ikuhara, Y. On the Quantitativeness of EDS STEM. Ultramicroscopy 2015, 151, 150159.

(34) Egerton, R. F. Electron Energy-Loss Spectroscopy in the TEM. Rep. Prog. Phys. 2009, 72, 016502.

(35) Kothleitner, G.; Grogger, W.; Dienstleder, M.; Hofer, F. Linking TEM Analytical Spectroscopies for an Assumptionless Compositional Analysis. Microsc. Microanal. 2014, 20, 678-686.

(36) Muller, D. A. Structure and Bonding at the Atomic Scale by Scanning Transmission Electron Microscopy. Nat. Mater. 2009, 8, 263-270.

(37) Kothleitner, G.; Neish, M. J.; Lugg, N. R.; Findlay, S. D.; Grogger, W.; Hofer, F.; Allen, L. J. Quantitative Elemental Mapping at Atomic Resolution Using X-Ray Spectroscopy. Phys. Rev. Lett. 2014, $112,085501$.

(38) Ramasse, Q. M.; Seabourne, C. R.; Kepaptsoglou, D.-M.; Zan, R.; Bangert, U.; Scott, A. J. Probing the Bonding and Electronic Structure of Single Atom Dopants in Graphene with Electron Energy Loss Spectroscopy. Nano Lett. 2013, 13, 4989-4995.

(39) Giannuzzi, L. A.; Stevie, F. A. A Review of Focused Ion Beam Milling Techniques for TEM Specimen Preparation. Micron 1999, 30, 197-204.

(40) Wirth, R. Focused Ion Beam (FIB) Combined with SEM and TEM: Advanced Analytical Tools for Studies of Chemical Composition, Microstructure and Crystal Structure in Geomaterials on a Nanometre Scale. Chem. Geol. 2009, 261, 217-229.

(41) Ade, H.; Zhang, X.; Cameron, S.; Costello, C.; Kirz, J.; Williams, S. Chemical Contrast in X-Ray Microscopy and Spatially Resolved XANES Spectroscopy of Organic Specimens. Science 1992, 258, 972-975.

(42) Varlot, K.; Martin, J. M.; Gonbeau, D.; Quet, C. Chemical Bonding Analysis of Electron-Sensitive Polymers by EELS. Polymer 1999, 40, 5691-5697.

(43) Vollmer, C.; Kepaptsoglou, D.; Leitner, J.; Busemann, H.; Spring, N. H.; Ramasse, Q. M.; Hoppe, P.; Nittler, L. R. FluidInduced Organic Synthesis in the Solar Nebula Recorded in Extraterrestrial Dust from Meteorites. Proc. Natl. Acad. Sci. U. S. A. 2014, 111, 15338-15343.

(44) Nitiputri, K.; Ramasse, Q. M.; Autefage, H.; McGilvery, C. M.; Boonrungsiman, S.; Evans, N. D.; Stevens, M. M.; Porter, A. E. Nanoanalytical Electron Microscopy Reveals a Sequential Mineralization Process Involving Carbonate-Containing Amorphous Precursors. ACS Nano 2016, 10, 6826-6835.

(45) Kłosowski, M. M.; Carzaniga, R.; Abellan, P.; Ramasse, Q.; McComb, D. W.; Porter, A. E.; Shefelbine, S. J. Electron Microscopy Reveals Structural and Chemical Changes at the Nanometer Scale in the Osteogenesis Imperfecta Murine Pathology. ACS Biomater. Sci. Eng. 2017, 3, 2788-2797.

(46) Bernier, N.; Bocquet, F.; Allouche, A.; Saikaly, W.; Brosset, C.; Thibault, J.; Charaï, A. A Methodology to Optimize the Quantification of sp2 Carbon Fraction from K Edge EELS Spectra. J. Electron Spectrosc. Relat. Phenom. 2008, 164, 34-43.

(47) Kongshaug, K. O.; Fjellvåg, H.; Lillerud, K. P. Synthesis and Crystal Structure of the Hydrated Magnesium Diphosphate $\mathrm{Mg} 2 \mathrm{P} 2 \mathrm{O} 7 \cdot 3.5 \mathrm{H} 2 \mathrm{O}$ and Its High Temperature Variant $\mathrm{Mg} 2 \mathrm{P} 2 \mathrm{O} 7$. H2O. Solid State Sci. 2000, 2, 205-214. 
(48) Pokroy, B.; Fitch, A.; Zolotoyabko, E. The Microstructure of Biogenic Calcite: A View by High-Resolution Synchrotron Powder Diffraction. Adv. Mater. 2006, 18, 2363-2368.

(49) Duguid, J.; Bloomfield, V. A.; Benevides, J.; Thomas, G. J., Jr. Raman Spectroscopy of DNA-Metal Complexes. I. Interactions and Conformational Effects of the Divalent Cations: $\mathrm{Mg}, \mathrm{Ca}, \mathrm{Sr}, \mathrm{Ba}, \mathrm{Mn}$, $\mathrm{Co}, \mathrm{Ni}, \mathrm{Cu}, \mathrm{Pd}$, and Cd. Biophys. J. 1993, 65, 1916-1928.

(50) Duguid, J. G.; Bloomfield, V. A.; Benevides, J. M.; Thomas, G. J., Jr. Raman Spectroscopy of DNA-Metal Complexes. II. The Thermal Denaturation of DNA in the Presence of $\mathrm{Sr} 2+, \mathrm{Ba} 2+, \mathrm{Mg} 2+$, $\mathrm{Ca} 2+, \mathrm{Mn} 2+, \mathrm{Co} 2+, \mathrm{Ni2}+$, and Cd2+. Biophys. J. 1995, 69, 26232641.

(51) Deng, H.; Bloomfield, V. A.; Benevides, J. M.; Thomas, G. J., Jr. Dependence of the Raman Signature of Genomic B-DNA on Nucleotide Base Sequence. Biopolymers 1999, 50, 656-666.

(52) Pemberton, J. E.; Latifzadeh, L.; Fletcher, J. P.; Risbud, S. H. Raman Spectroscopy of Calcium Phosphate Glasses with Varying Calcium Oxide Modifier Concentrations. Chem. Mater. 1991, 3, 195200.

(53) De Gelder, J. D.; De Gussem, K. D.; Vandenabeele, P.; Moens, L. Reference Database of Raman Spectra of Biological Molecules. J. Raman Spectrosc. 2007, 38, 1133-1147.

(54) Zhu, G.; Zhu, X.; Fan, Q.; Wan, X. Raman Spectra of Amino Acids and Their Aqueous Solutions. Spectrochim. Acta, Part A 2011, $78,1187-1195$

(55) Japaridze, A.; Vobornik, D.; Lipiec, E.; Cerreta, A.; Szczerbinski, J.; Zenobi, R.; Dietler, G. Toward an Effective Control of DNA's Submolecular Conformation on a Surface. Macromolecules 2016, 49, 643-652.

(56) Kypr, J.; Kejnovská, I.; Renčiuk, D.; Vorlícková, M. Circular Dichroism and Conformational Polymorphism of DNA. Nucleic Acids Res. 2009, 37, 1713-1725.

(57) Gray, D. M.; Ratliff, R. L.; Vaughan, M. R. [19] Circular Dichroism Spectroscopy of DNA. Methods Enzymol. 1992, 211, 389406.

(58) Zhao, Z.; Fu, J.; Dhakal, S.; Johnson-Buck, A.; Liu, M.; Zhang, T.; Woodbury, N. W.; Liu, Y.; Walter, N. G.; Yan, H. Nanocaged Enzymes with Enhanced Catalytic Activity and Increased Stability Against Protease Digestion. Nat. Commun. 2016, 7, 10619.

(59) Ahn, S. J.; Costa, J.; Emanuel, J. R. PicoGreen Quantitation of DNA: Effective Evaluation of Samples Pre- or Post-PCR. Nucleic Acids Res. 1996, 24, 2623-2625.

(60) Liu, M.; Hui, C. Y.; Zhang, Q.; Gu, J.; Kannan, B.; JahanshahiAnbuhi, S.; Filipe, C. D. M.; Brennan, J. D.; Li, Y. Target-Induced and Equipment-Free DNA Amplification with a Simple Paper Device. Angew. Chem., Int. Ed. 2016, 55, 2709-2713.

(61) Leinweber, P.; Kruse, J.; Walley, F. L.; Gillespie, A.; Eckhardt, K.-U.; Blyth, R. I. R.; Regier, T. Nitrogen K-edge XANES - An Overview of Reference Compounds Used to Identify 'Unknown' Organic Nitrogen in Environmental Samples. J. Synchrotron Radiat. 2007, 14, 500-511.

(62) Cody, G. D.; Ade, H.; Alexander, C. M. O’D.; Araki, T.; Butterworth, A.; Fleckenstein, H.; Flynn, G.; Gilles, M. K.; Jacobsen, C.; Kilcoyne, A. L. D.; Messenger, K.; Sanford, S. A.; Tyliszczak, T.; Westphal, A. J.; Wirick, S.; Yabuta, H. Quantitative Organic and Light-Element Analysis of Comet 81P/Wild 2 Particles Using C-, N-, and O- $\mu$-XANES. Meteorit. Planet. Sci. 2008, 43, 353-365.

(63) Lehmann, J.; Solomon, D.; Brandes, J.; Fleckenstein, H.; Jacobsen, C.; Thieme, J. Synchrotron-Based Near-Edge X-Ray Spectroscopy of Natural Organic Matter in Soils and Sediments. In Biophysico-Chemical Processes Involving Natural Nonliving Organic Matter in Environmental Systems; Senesi, N., Xing, B., Huang, P. M., Eds.; John Wiley \& Sons: Hoboken, NJ, 2009; pp 729-781.

(64) Kłosowski, M. M.; Friederichs, R. J.; Nichol, R.; Antolin, N.; Carzaniga, R.; Windl, W.; Best, S. M.; Shefelbine, S. J.; McComb, D. W.; Porter, A. E. Probing Carbonate in Bone Forming Minerals on the Nanometre Scale. Acta Biomater. 2015, 20, 129-139. 